\title{
Current Evidence on the Efficacy of Gluten-Free Diets in Multiple Sclerosis, Psoriasis, Type 1 Diabetes and Autoimmune Thyroid Diseases
}

\author{
Moschoula Passali ${ }^{1,2}$, Knud Josefsen ${ }^{3}$, Jette Lautrup Frederiksen ${ }^{1,2, *}$ and \\ Julie Christine Antvorskov ${ }^{3}$ \\ 1 Multiple Sclerosis Clinic, Department of Neurology, Rigshospitalet-Glostrup, Valdemar Hansens Vej 13, \\ 2600 Glostrup, Denmark; passali@nexs.ku.dk \\ 2 Department of Clinical Medicine, Faculty of Health Sciences, University of Copenhagen, Blegdamsvej 3B, \\ 2200 Copenhagen N, Denmark \\ 3 The Bartholin Institute, Rigshospitalet, Ole Maaløes Vej 5, 2200 Copenhagen, Denmark; knud@eln.dk (K.J.); \\ julie.antvorskov@gmail.com (J.C.A.) \\ * Correspondence: jette.lautrup.battistini@regionh.dk
}

Received: 15 July 2020; Accepted: 30 July 2020; Published: 1 August 2020

\begin{abstract}
In this review, we summarize the clinical data addressing a potential role for gluten in multiple sclerosis (MS), psoriasis, type 1 diabetes (T1D) and autoimmune thyroid diseases (ATDs). Furthermore, data on the prevalence of celiac disease (CD) and gluten-related antibodies in the above patient groups are presented. Adequately powered and properly controlled intervention trials investigating the effects of a gluten-free diet (GFD) in non-celiac patients with MS, psoriasis, T1D or ATDs are lacking. Only one clinical trial has studied the effects of a GFD among patients with MS. The trial found significant results, but it is subject to major methodological limitations. A few publications have found beneficial effects of a GFD in a subgroup of patients with psoriasis that were seropositive for anti-gliadin or deamidated gliadin antibodies, but no effects were seen among seronegative patients. Studies on the role of gluten in T1D are contradictive, however, it seems likely that a GFD may contribute to normalizing metabolic control without affecting levels of islet autoantibodies. Lastly, the effects of a GFD in non-celiac patients with ATDs have not been studied yet, but some publications report that thyroid-related antibodies respond to a GFD in patients with concomitant CD and ATDs. Overall, there is currently not enough evidence to recommend a GFD to non-celiac patients with MS, psoriasis, ATDs or T1D.
\end{abstract}

Keywords: gluten; gluten-free diet; gliadin; autoimmunity; neurology; multiple sclerosis; psoriasis; autoimmune thyroid disease; type 1 diabetes; celiac disease

\section{Introduction}

Wheat is a major component of Western diets, however, abstaining from gluten is becoming a popular trend [1]. Adhering to a lifelong gluten-free diet (GFD) is the current treatment for celiac disease (CD) — an immune-mediated small intestinal enteropathy triggered by the ingestion of gluten [2]. It has been hypothesized that gluten may contribute to deteriorating the course of immune-mediated disorders [3-5]. According to a U.S. national survey, a GFD was the most common special diet to be used by patients with psoriasis [6]. Similarly, an American dietary survey found that $5.6 \%$ of the surveyed patients with multiple sclerosis (MS) reported adhering to a GFD [7], whereas in an Australian survey, a GFD was adopted by $16.4 \%$ of the included patients with MS [8]. Type 1 diabetes (T1D) and autoimmune thyroid diseases (ATDs) affect the endocrine system. The contribution of dietary factors to the pathogenesis of autoimmune endocrine disorders is currently an active research 
area. This review summarizes the currently available clinical data on a potential involvement of gluten in MS, psoriasis, T1D and ATDs.

\section{Gluten}

Gluten proteins have long been of interest to the food industry due to their high impact on the baking quality of wheat flours $[9,10]$. From a chemical perspective, gluten has been defined as the proteinaceous mass that remains when wheat dough is washed with water and consists primarily of the prolamin and glutelin fractions of the storage proteins of wheat [11,12]. The terms prolamin and glutelin originate from the classification of grain proteins into four fractions according to their solubility properties (Osborne fractions) [13]. Prolamins are insoluble in water but soluble in alcohol, whereas glutelins are insoluble in both water and alcohol [14]. The terms gliadin and glutenin account for the prolamin and glutelin fractions of wheat, whereas the terms secalin, hordein and avenin describe the prolamin fraction of rye, barley and oats, respectively [14]. Likewise, the glutelin fractions of rye and barley are commonly described as secalinin and hordenin, however, similar terminology does not apply for oat glutelins [12]. Codex Alimentarius has defined gluten as "a protein fraction from wheat, rye, barley, oats or their crossbred varieties and derivatives thereof, to which some persons are intolerant and that is insoluble in water and $0.5 \mathrm{M} \mathrm{NaCl}^{\prime \prime}$ [15]. As a result, gluten is nowadays considered to be a common term for the prolamin and glutelin fractions of wheat, rye, barley and, in some cases, oats.

Gluten proteins contain repetitive sequence sections that are rich in the amino acids proline and glutamine $[14,16]$. Such sections cannot be fully degraded by the human gastrointestinal enzymes $[10,13]$, resulting in the presence of relatively long gluten peptides in the small intestine. In patients with $C D$, such gluten peptides trigger an inflammatory reaction, however, their presence in the small intestine of most healthy individuals is believed to be rather unproblematic. In vitro studies using caco-2 cell lines $[17,18]$ as well as ex vivo studies on human biopsy explants from both CD patients and healthy controls (HCs) $[18,19]$, suggest that exposure to gliadin disrupts the integrity of the intestinal epithelium. The effect of gliadin on intestinal permeability is believed to be mediated through the secretion of the protein zonulin [20]. Zonulin has been identified as prehaptoglobin-2 [21] and serum zonulin is often used as a marker of intestinal permeability. Levels of zonulin have been found to be elevated in autoimmune diseases [22-25], however, widely used ELISA kits cross-react with proteins, such as properdin and complement C3 [26,27], which shows why caution should be practiced when interpreting data on this topic.

\section{Multiple Sclerosis}

Multiple sclerosis (MS) is an autoimmune, yet incurable, disease of the central nervous system [28] and one of the leading causes of disability among young adults. A recent publication reports that $31 \%$ (10/32) of websites providing MS-specific dietary advice recommend patients with MS to abstain from "grains (gluten)" [29]. Despite a high interest in the use of dietary modifications to ameliorate the course of the disease [30], MS-specific, evidence-based dietary guidelines have not been developed yet.

\subsection{Gluten-Free Interventions in Multiple Sclerosis}

The effects of a GFD among patients with MS have only been investigated by a single open label, non-randomized, controlled trial. Thirty-six patients, who followed a GFD for a median of 4.5 years (mean $5.3 \pm 1.6$ ), were compared with 36 patients who followed a regular diet [31]. At the end of the study, the group on the GFD had significantly lower disability measured by the expanded disability status scale (EDSS) (1.5 \pm 1.4 vs. $2.1 \pm 1.5, p=0.001$, baseline EDSS was 1.7 for both groups) and significantly lower activity on magnetic resonance imaging (MRI) $(28 \%$ vs. $67 \%, p=0.001)$ compared to the group on a regular diet [31]. There was no effect on annual relapse rate. Unfortunately, this study was subject to important limitations. Group allocation was performed by instructing all 72 patients to follow a GFD for the first six months of the study, whereafter non-compliant patients were asked to 
resume a regular gluten-containing diet. In addition, eight study participants were diagnosed with CD and they all remained in the GFD group, further supporting the idea that the method used for group allocation was suboptimal. Apart from above described methodological issues, major inconsistencies, including the use of the word "randomised" in the title of the study, reduce our capacity to trust this publication [31].

Eliminating gluten from the diet is also part of the "The Wahls Protocol", a multimodal lifestyle intervention including, among others, adherence to a modified paleolithic diet. Clinical studies have illustrated that "The Wahls Protocol" can contribute to improving primarily self-reported outcomes, such as mood, fatigue and quality of life among patients with relapsing remitting MS [32] and progressive MS [33-35]. The risk of placebo and/or nocebo effects should not be neglected when evaluating the results of lifestyle interventions. Furthermore, due to the multimodal nature of the interventions, it is not possible to quantify the effects of eliminating gluten from the diet. The lack of disease-specific endpoints is a major limitation of these studies. Nevertheless, these publications highlight that lifestyle modifications can contribute to improving the quality of life of patients with MS. This is of utmost importance for patients with the progressive forms of MS, as highly effective treatments for these patients are still lacking [36].

\subsection{Prevalence of Celiac Disease and Gluten-Related Serology in Multiple Sclerosis}

Several publications have reported the prevalence of gluten-related antibodies among patients with MS. Among six studies estimating the prevalence of seropositivity for anti-gliadin (AGA) immunoglobulins (Ig) in patients with MS [37-42], only one study found a significantly higher prevalence of IgG-AGA among patients with MS (7/98) compared to HCs $(2 / 140)(p=0.03)$ [42]. However, when investigating whether patients with MS have elevated mean values of IgA-AGA or IgG-AGA compared to HCs, the results are highly contradictive [38,42-44]. We can therefore not exclude that patients with MS may have slightly elevated AGA titers compared to HCs, however, this is still far from sufficiently different for diagnostic use.

Data from twelve studies [37-48] estimating the prevalence of seropositivity for IgA tissue transglutaminase (tTG) in patients with MS do not support an increased prevalence of CD among patients with MS, whereas a single study found higher mean values of IgA-tTG and IgG-tTG among 30 patients with MS compared to $25 \mathrm{HCs}$ [49]. So far, only one publication supports an association between $\mathrm{CD}$ and MS by reporting the prevalence of $\mathrm{CD}$ to be $11 \%$ in a cohort of 72 patients with relapsing remitting MS and 32\% (23/126) among their first-degree relatives [50]. According to the last-mentioned study, the diagnosis of MS was made at a younger age among celiac ( $35+/-7$ years) compared to non-celiac $(44+/-10$ years) patients $(p<0.05)$ [50]. For an overview of studies measuring other gluten- and celiac-related antibodies among patients with MS, the reader is referred to Thomsen et al. (2019) [51].

The most powerful studies investigating a potential association between CD and MS are two Danish population-based studies [52,53] and a Swedish case-control study including 14,371 CD patients and 70,096 reference individuals [54], however, none of them found any association. The first Danish study investigated the comorbidity of 31 autoimmune diseases and calculated an odds ratio (OR) of 1.0 for CD and MS [52]. The second Danish study investigated the prevalence of autoimmune comorbidities among patients with $\mathrm{CD}$ and failed to find an increased prevalence of MS among patients with CD. According to the Swedish case-control study, the presence of CD did not increase the risk of subsequent MS diagnosis (hazard ratio $(\mathrm{HR})=0.9 ; 95 \%$ confidence interval $(\mathrm{CI})=(0.3-2.3)$ ) [54] . Lastly, two French studies estimated the prevalence of MS among patients with CD to be $0.11 \%$ (1/924) [55] and $0.14 \%$ (1/741) [56]. This is similar to the crude estimate of MS in the French population, which is $0.15 \%$ [57]. 


\section{Psoriasis}

Psoriasis is a chronic autoimmune skin disease characterized by the development of erythematous scaly lesions. Psoriasis vulgaris, also known as plaque psoriasis, is the most common type of psoriasis, but several other types of psoriasis also exist [58]. The Medical Board of the National Psoriasis Foundation conducted a systematic review in 2018 with the aim of developing nutritional recommendations for patients with psoriasis or psoriatic arthritis [59]. The board states "We weakly recommend a gluten-free diet only in patients who test positive for serologic markers of gluten sensitivity" [59]. The popularity of the GFD among patients with psoriasis is highlighted in a U.S. study from 2017 , in which $38 \%$ of the responding patients $(n=1206)$ reported avoiding gluten and $53.4 \%(247 / 459)$ of them reported to have experienced an improvement or clearance of their disease as a result of the GFD [6].

\subsection{Intake of Gluten and Risk of Psoriasis}

Using data from the Nurses' Health Study II, a publication examined whether higher intakes of gluten were associated with a higher risk of future psoriasis, psoriatic arthritis and atopic dermatitis [60]. When comparing the highest and lowest gluten intake quintiles, the multivariate HRs were $1.15(95 \% \mathrm{CI}$ $=(0.98-1.36)), 1.12(95 \% \mathrm{CI}=(0.78-1.62))$ and $0.91(95 \% \mathrm{CI}=(0.66-1.25))$ for psoriasis, psoriatic arthritis and atopic dermatitis, respectively. No dose-response relationship was observed, but the fact that the effect of a strictly GFD was not investigated is a minor limitation of this study.

\subsection{Gluten-Free Interventions in Psoriasis}

The potential role of gluten in psoriasis has been addressed in several publications from Michaëlsson and his colleagues. In 2000, they published a study illustrating clinical improvement in $73 \%$ (22/30) of patients who adhered to a GFD for three months (reduction of psoriasis area and severity index (PASI) score from $5.5 \pm 4.5$ to $3.6 \pm 3.0(p=0.001)$ ) [61]. All patients were positive for IgA-AGA or IgG-AGA and no clinical improvement was observed among six seronegative patients who also adhered to a GFD. The study was originally designed as a cross-over trial and, after three months on a GFD, the participants had to reintroduce gluten to their diet for three months. However, the last part of the study was discontinued as 60\% (18/30) of the AGA-positive patients, but none of the seronegative patients, required increased treatment due to a worsening of their skin lesions after the reintroduction of dietary gluten [61]. Immunohistochemical analyses of skin biopsies from 19 of the above seropositive patients were later published in a separate publication that revealed a reduction in Ki67 positive cells in the involved dermis after the GFD [62]. Moreover, a higher expression of tTG was found in involved, compared to uninvolved, dermis (5.06 $\pm 3.80 \%$ vs. $0.67 \pm 0.54 \%, n=13, p=0.0002)$ and the GFD resulted in a drop in tTG expression in the dermis by $50 \%$ [62].

Similarly, in 2007 Michaëlsson et al. presented results from 16 cases of palmoplantar pustulosis, who adhered to a GFD [63]. AGA-seropositive patients who strictly adhered to the GFD $(n=9)$ experienced great improvements or even the clearance of their lesions. Improvements were only seen in two out of four patients with lower compliance to the GFD and none of the seronegative patients $(n=3)[63]$.

According to a more recent publication by Kolchak et al. in 2018, a one-year gluten-free intervention resulted in a $56 \%$ and $36 \%$ improvement in the PASI score in patients with very high $(>30 \mathrm{U} / \mathrm{ml}, n=5)$ and high (11.5-30.0 U/ml, $n=8$ ) levels of IgA against gliadin peptides (not clear whether native or deamidated gliadin), respectively [64]. As no other antibodies were measured and biopsies were not performed, it is not known whether some of the included patients suffered from CD. The effects of a GFD in patients with concomitant psoriasis and CD have been explored in an Italian multicenter study [65]. At a three-month follow-up, patients $(n=9)$ experienced major improvements in their PASI scores (two by at least 50\%, five by at least 75\%, total clearance in one patient and one drop-out). A single patient had worsened by the six-month follow-up, whereas most patients maintained their 
clinical improvement $(n=5)$ and two patients further improved [65]. Overall, evidence suggests that psoriasis patients with gluten-related antibodies may benefit from a GFD, however, larger trials are still lacking.

\subsection{Gluten-Related Serology in Psoriasis}

According to a meta-analysis from 2014, both the prevalence of seropositivity for IgA-AGA, as well as mean values of IgA-AGA, are higher among patients with psoriasis compared to HCs [66]. To illustrate the heterogeneity among studies, an overview of identified case-control publications is provided in Table 1. Additional studies have described the prevalence of AGA seropositivity among patients with psoriasis [67,68] and palmoplantar pustulosis [63] without including a relevant control group. Moreover, most studies [69-72] have found significantly higher concentrations of IgA-AGA among patients with psoriasis compared to HCs, whereas one study [73] did not. Regarding IgG-AGA, only one [71] out of four studies [70,72,73] found higher concentrations in patients with psoriasis compared to HCs. Using a different approach, no difference was found in the proliferative response of peripheral blood mononuclear cells from patients with psoriasis $(n=37)$ and HCs $(n=37)$ after stimulation with wheat peptides, however, the five highest responses against peptide p62-75 were observed among patients with psoriasis [74].

Table 1. Case-control studies estimating the prevalence of IgA-AGA and IgG-AGA in patients with psoriasis and HCs. Results are presented as "number of seropositive individuals"/"number of individuals tested". HCs: healthy controls, Ig: immunoglobulin, AGA: antigliadin antibody, NA: not available, NS: not significant.

\begin{tabular}{ccccccc}
\hline Case-Control Studies & $\begin{array}{c}\text { IgA-AGA } \\
\text { in Psoriasis }\end{array}$ & $\begin{array}{c}\text { IgA-AGA } \\
\text { in HCs }\end{array}$ & $p$-Value & $\begin{array}{c}\text { IgG-AGA } \\
\text { in Psoriasis }\end{array}$ & $\begin{array}{c}\text { IgG-AGA } \\
\text { in HCs }\end{array}$ & $p$-Value \\
\hline Akbulut 2013 [75] & $6 / 37$ & $1 / 50$ & $p=0.039$ & $3 / 37$ & $0 / 50$ & $p=0.073$ \\
Cardinali 2002 [76] & $0 / 39$ & $0 / 39$ & NS & $2 / 39$ & $0 / 39$ & NA \\
Kalayciyan 2006 [77] & $21 / 127$ & $3 / 31$ & NS & - & - & - \\
Kia 2007 [78] & $6 / 200$ & $5 / 100$ & NS & $32 / 200$ & $16 / 100$ & NS \\
${ }^{1}$ Kolchak 2018 [64] & $13 / 97$ & $2 / 91$ & NA & - & - & - \\
Lesiak 2016 [79] & $0 / 20$ & $0 / 29$ & NS & - & - & - \\
Nagui 2010 [69] & $14 / 41$ & $1 / 41$ & NA & - & - & - \\
Singh 2010 [71] & $8 / 56$ & $0 / 60$ & $p<0.05$ & $12 / 56$ & $0 / 60$ & $p<0.05$ \\
Sultan 2010 [73] & $8 / 120$ & $9 / 120$ & NS & $5 / 120$ & $6 / 120$ & NS \\
\hline In total & $76 / 737$ & $21 / 561$ & - & $54 / 452$ & $22 / 369$ & - \\
\hline
\end{tabular}

${ }^{1}$ Possibly measures of antibodies against deamidated gliadin peptide.

To investigate whether gluten-related antibodies correlate with disease activity in psoriasis, a study screened 130 patients for IgG-AGA, IgA-AGA and IgA-tTG and identified 21 patients (16.2\%) who were positive for at least one of the antibodies [80]. Psoralen and ultraviolet A (PUVA) phototherapy (57\% vs. $30 \%, p=0.03$ ) and systemic therapy ( $48 \%$ vs. $22 \%, p=0.04)$ was currently given or had previously been given to a higher percentage of seropositive compared to seronegative patients. There was no difference for ultraviolet B (UVB) phototherapy and the presence of arthritis or arthralgia [80]. A similar but smaller study $(n=41)$ found a significant relationship between seropositivity for IgA-AGA and disease duration $(p<0.001)$, however, being seropositive was not related to PASI scores [69]. In contrast, in a study with 120 patients with psoriasis (eight seropositive for IgA-AGA/five seropositive for IgG-AGA), severe disease at the reported time or past treatment for high disease severity was not associated with seropositivity for AGA [73]. 
According to a publication from 2020 that tested for antibodies against an array of 75 antigens, IgG4 antigliadin antibodies were the only antibodies to be elevated in the sera of 12 patients with severe psoriasis (PASI > 30) [81]. IgG4 antigliadin antibodies were not present in sera from $12 \mathrm{HCs}$. Later validation, using a cohort with 73 psoriasis patients and $75 \mathrm{HCs}$, resulted in an area under the curve of $0.98(p<0.001)$ in the receiver operating characteristic (ROC) analysis, suggesting that IgG4 antigliadin antibodies could potentially function as a diagnostic biomarker for psoriasis. For a subgroup of patients with the highest levels of anti-gliadin IgG4, there was a significant correlation between antibody levels and PASI scores $(r=0.65, p<0.001)$ [81].

With regard to the prevalence of IgA-tTG antibodies in psoriasis, we have identified five cross-sectional cohort studies $[63,68,80,82,83]$ and ten case-control studies $[65,69,71,75,76,84-88]$ (previously mentioned in Table 2). In addition, a study of 67 patients with psoriasis and 85 HCs found significantly elevated mean values of IgA-tTG in patients with psoriasis $(0.943 \pm 1.131$ vs. $0.852 \pm$ $0.576, p<0.05$ ) [71]. Many case-control studies fail to reveal a significant difference between groups, however, it must be stressed that the majority of studies on the topic are underpowered, considering the fact that the global seroprevalence of $\mathrm{CD}$ has been estimated to be $1.4 \%$ [89].

Table 2. Case-control studies estimating the prevalence of IgA-tTG in patients with psoriasis and HCs. Results are presented as "number of seropositive individuals"/“number of individuals tested". HCs: healthy controls, IgA-tTG: class A immunoglobulins against tissue transglutaminase, NA: not available, NS: not significant.

\begin{tabular}{cccc}
\hline Case-Control Studies & IgA-tTG in Psoriasis & IgA-tTG in HCs & $p$-Value \\
\hline Akbulut 2013 [75] & $1 / 37$ & $0 / 50$ & NS \\
Bastiani 2015 [65] & $9 / 218$ & $1 / 264$ & $p<0.05$ \\
Cardinali 2002 [76] & $1 / 39$ & $0 / 39$ & $\mathrm{NS}$ \\
Hull 2008 [84] & $0 / 37$ & $1 / 53$ & $\mathrm{NS}$ \\
Juzlova 2016 [85] & $2 / 189$ & $0 / 378$ & $p=0.045$ \\
Montesu 2011 [86] & $2 / 100$ & $0 / 100$ & $\mathrm{NS}$ \\
Nagui 2010 [69] & $14 / 41$ & $9 / 41$ & $\mathrm{NA}$ \\
Ojetti 2003 [87] & $2 / 92$ & $0 / 90$ & $\mathrm{NA}$ \\
Riente 2004 [88] & $1 / 75$ & $3 / 78$ & $\mathrm{NS}$ \\
Singh 2010 [71] & $6 / 56$ & $0 / 60$ & $p=0.01$ \\
\hline In total & $38 / 884$ & $14 / 1153$ & - \\
\hline
\end{tabular}

\subsection{Comorbidity between Celiac Disease and Psoriasis}

Results from 18 publications included in a systematic review and meta-analysis from 2019 are summarized below [90]. Out of two studies investigating the incidence of $\mathrm{CD}$ among patients with psoriasis, only one found a statistically significant increased risk $(\mathrm{HR}=1.9,95 \% \mathrm{CI}=(1.6-2.2)[91]$ and $\mathrm{HR}=1.20,95 \% \mathrm{CI}=(0.91-1.59))$ [92]. Similarly, two studies estimated the incidence of psoriasis among patients with $\mathrm{CD}$, but in this case, both studies found significant results (HR $=1.72$, $95 \% \mathrm{CI}=(1.54-1.92)$ [93] and $\mathrm{HR}=1.9,95 \% \mathrm{CI}=(1.5-2.3)$ [91]). With regard to the prevalence of CD in patients with psoriasis or psoriatic arthritis, significantly increased ORs were found in five $[65,92,94-96]$ out of nine $[86,87,97,98]$ studies (meta-analysis: $\mathrm{OR}=2.16,95 \% \mathrm{CI}=(1.74-2.69)$ [90]). Likewise, the prevalence of psoriasis among patients with $C D$ was found to be increased in four $[53,93,99,100]$ out of eight [101-104] publications (meta-analysis: $\mathrm{OR}=1.8,95 \% \mathrm{CI}=(1.36-2.38)$ [90]). The two-way meta-analysis concluded that clinicians should be aware of the significant association between $C D$ and psoriasis [90].

\section{Type 1 Diabetes}

T1D is a chronic, autoimmune disease characterized by the destruction of the insulin-producing beta cells in the pancreas. T1D is often diagnosed in childhood and results in a lifelong need for exogenous insulin. Several animal studies support the potential involvement of gluten in the 
pathogenesis of T1D [105] and have previously been summarized by Antvorskov et al. [105] and Haupt-Jorgensen et al. [106].

\subsection{Exposure to Gluten during Early Life and Risk of Type 1 Diabetes}

Recent mother and child cohort studies suggest that exposure to gluten during early life may affect the risk of developing T1D [107,108], whereas earlier studies among predisposed individuals did not reveal such an association [109,110]. According to a Danish study from 2018 [107], offspring from mothers with the highest intake of gluten had a twofold higher risk of developing T1D compared to offspring from mothers with the lowest intake of gluten during pregnancy (adjusted $H R=2.00$, $95 \% \mathrm{CI}=(1.02-4.00))$. A dose-response relationship was demonstrated, however, only the difference between the groups with the highest and lowest intakes of gluten reached statistical significance. These results were not replicated in a similar Norwegian study from 2020 [108] but, this time, the intake of gluten by the offspring themselves was associated with a higher risk of T1D (adjusted HR $=1.46$, $95 \% \mathrm{CI}=(1.06-2.01), p=0.02)$.

Similarly, publications have explored whether and how infant feeding patterns could affect the risk of T1D [105]. Data from the Diabetes Autoimmunity Study in the Young (DAISY) support that introduction of cereals between the age of 4-6 months leads to the lowest risk of islet autoimmunity $(<4$ months: $\mathrm{HR}=4.32,95 \% \mathrm{CI}=(2.0-9.35),>6$ months: $\mathrm{HR}=5.36,95 \% \mathrm{CI}=(2.08-13.8))$ [111]. Likewise, the late ( $\geq 7$ months) introduction of gluten-containing porridge has been found to be a risk factor for the development of $\beta$-cell autoantibodies [112], whereas Ludvigsson [113] did not find an association between the time of the introduction of gluten and levels of islet autoantibodies. Results from the BABYDIAB study support the idea that the introduction of gluten-containing foods at or before the age of three months increases the risk of islet autoimmunity $(\mathrm{HR}=5.2,95 \% \mathrm{CI}=(1.7-15.5)$, $p=0.003)$, however, the late ( $>6$ months) introduction of gluten-containing foods was not associated with increased risk of islet autoimmunity [114]. Lastly, the BABYDIET study—a pilot study in which 150 infants at high risk of T1D where randomized to either control (6 months) or late (12 months) introduction of gluten-did not find any difference in islet autoimmunity at three years in the per protocol analysis $($ compliance $=70 \%)[115]$.

\subsection{Gluten-Free Interventions in Type 1 Diabetes}

Two studies have investigated whether a GFD could have a protective effect among children with a high risk of developing T1D. In the first study, 17 first-degree relatives of T1D patients with at least two $\beta$-cell autoantibodies were included in a cross-over trial consisting of six months on a GFD followed by six months on a gluten-containing diet [116]. Glucose tolerance tests revealed an improved acute insulin response after the GFD $(p=0.004)$ and a non-significant deterioration after the reintroduction of dietary gluten $(p=0.07)$. The results were similar for insulin sensitivity measured by the homeostasis model of insulin resistance (HOMA-IR), however, this time, a non-significant increase after the GFD was followed by a significant decrease $(p<0.005)$ after the gluten-containing diet. An effect on the levels of autoantibodies was neither observed in this study [116] nor in a similar study with a longer gluten-free intervention of 12 months $(n=7)$ [117]. A five-year follow-up to the latter study suggests that the 12 months on a GFD did not affect the risk of progressing to T1D [117].

In 2012, a case report suggested that a GFD introduced 2-3 weeks after the diagnosis of T1D may have prolonged remission in a five-year-old boy without $\mathrm{CD}$ [118]. Both his $\mathrm{HbA1c}$ and his fasting blood glucose stabilized without insulin therapy and, twenty months after diagnosis, he still remained without the need for daily insulin therapy [118]. This case led to the performance of a Danish pilot study evaluating the effects of a one-year gluten-free intervention among 15 children with newly diagnosed T1D [119]. Compared to two previous reference cohorts, the children on the GFD had a 21\% lower $\mathrm{HbA1c}$ and a higher prevalence of partial remission (insulin dose-adjusted A1c (IDAA1c) $\leq 9$ ), but no difference was seen in stimulated C peptide [119]. 
Prolonged partial remission in response to a GFD was also illustrated in a study that was methodologically stronger due to the inclusion of a control group which remained on a standard gluten-containing diet $(n=19)$ during the study time [120]. The trial was not randomized and 20 out of 26 children completed the one-year gluten-free intervention with satisfactory compliance. The GFD was introduced within a median of 38 days from the onset of T1D. At follow-up, the children adhering to the GFD had a lower IDAA1c (by 1.37; $p=0.01$ ), a lower mean $\mathrm{HbA} 1 \mathrm{c}$ (by $0.7 \%(7.8 \mathrm{mmol} / \mathrm{mol})$; $p=0.02$ ) and there was a tendency towards a lower insulin dose (by $0.15 \mathrm{U} / \mathrm{kg} / \mathrm{day} ; p=0.07$ ) compared to the control group [120]. Last, but not least, several studies have investigated whether a GFD affects metabolic control in individuals with both CD and T1D [121-142] (presented in Table A1 in Appendix A).

\subsection{Prevalence of Celiac Disease and Gluten-Related Serology in Type 1 Diabetes}

A systematic review and meta-analysis published in 2014 calculated the prevalence of biopsy-confirmed CD among patients with T1D to be $6.0 \%(95 \% \mathrm{CI}=(5.0-6.9 \%))$ [143]. Similarly, a systematic review and meta-analysis from 2019 reports the weighted prevalence of CD and any gluten-related antibodies among patients with T1D to be $4.7 \%(95 \% \mathrm{CI}=(4.0-5.5))$ and $10.2 \%$ $(95 \% \mathrm{CI}=(8.4-12.7))$, respectively [144]. Among gluten-related antibodies, the highest weighted prevalence was estimated for IgG-AGA as $12.7 \%(95 \% \mathrm{CI}=(6.1-21.0))$ [144]. Equally relevant, a Swedish population cohort study has estimated the HR of subsequent T1D before the age of 20 years to be 2.4 $(95 \% \mathrm{CI}=(1.9-3.0), p<0.001)$ among patients with CD [145].

Although the association between $\mathrm{CD}$ and T1D is well supported, the heterogeneity among studies is large. A better understanding of the factors that contribute to this variation may therefore be relevant. With regard to measurements of gluten-related antibodies, technical differences in the analytical assays being used may hinder direct comparisons among publications highlighting the importance of including a healthy control group in all studies. This is especially relevant for AGA due to their lower specificity for $\mathrm{CD}$ and the fact that biological factors may contribute to their variation within healthy populations.

The meta-analysis by Elfström et al. [143] revealed that CD was less frequent in adults $(2.7 \%, 95 \% \mathrm{CI}=(2.1-3.3 \%))$ compared to children $(6.2 \%, 95 \% \mathrm{CI}=(6.1-6.3 \%))$ with T1D $(p<0.001)$. Tiberti et al. [146] on the contrary, found a significantly higher prevalence of gluten-related antibodies among patients with a high ( $>15$ years) compared to a low (5-15 years) duration of T1D. Similarly, Nederstigt et al. [144] reported that the prevalence of IgA-AGA increased with the duration of T1D, whereas endomysium antibodies decreased with age. Interestingly, IgA-tTG-seropositive patients with T1D have been found to have lower titers of IgG-tTG and deamidated gliadin peptide antibodies compared to CD patients without T1D [147]. In addition, longitudinal studies suggest that AGA titers can fluctuate over time [148] but also that diabetes-related antibodies may respond to a GFD in cases with CD [149]. Lastly, data from Salardi et al. [150] support that the prevalence of CD significantly increased among Italian patients with T1D after 1994, however, this might also reflect an increase in the prevalence of $\mathrm{CD}$ in the general population.

\section{Autoimmune Thyroid Diseases}

ATDs affect $2-5 \%$ of the population with a female predominance. The most common ATDs are Hashimoto's thyroiditis (HT) and Graves' disease, which lead to hypothyroidism and hyperthyroidism, respectively [114].

\subsection{Gluten-Free Interventions in Autoimmune Thyroid Diseases}

Few studies have investigated whether a GFD can contribute to ameliorating thyroid-related pathology among patients with concomitant $C D$, but we have not been able to identify publications exploring the effects of a GFD in ATDs in the absence of CD or celiac-related antibodies. 
A controlled trial has investigated the effects of six months on a GFD $(n=16)$ compared to no dietary intervention ( $n=18$ ) among drug-naive women with HT [151]. The GFD resulted in a drop in the levels of thyroid peroxidase (TPO) and thyroglobulin antibodies, an increase in 25-hydroxyvitamin $\mathrm{D}$ and an improvement in the structure parameter inference approach (SPINA)-GT index, which correlated with the changes in antibody titers. No effect was seen on levels of thyrotropin and free triiodothyronine. The study population included patients that were seropositive for IgA-tTG, however, no intestinal biopsies were performed and patients with symptomatic CD were excluded [151].

An Italian multicenter study evaluating the thyroid function of 128 patients with newly diagnosed CD before and one year after the introduction of a GFD reports that, in some patients, a GFD can reverse thyroid abnormalities [152]. Valentino et al. [153] also noted an improvement in symptoms related to hypothyroidism and thyroxine dosage among three ATD patients with concomitant CD that followed a GFD for six months. However, levels of thyroglobulin and TPO antibodies only changed for one patient, who had an additional follow-up at 18 months [153].

On the contrary, Mainardi et al. [154] report that a GFD did not seem to influence thyroid function and antibodies among two cases of concomitant CD and ATD. Likewise, a more recent study found no effect of one year on a GFD on levels of TPO antibodies that were present among 10 (37\%) patients with newly diagnosed CD [155]. On the contrary, thyroid volume significantly decreased compared to a group of patients without $\mathrm{CD}$, indicating that thyroiditis was continually progressing even after the establishment of a GFD [155]. It is possible that a longer study time is necessary to reveal an effect of a GFD, as TPO antibodies were only present among $76.9 \%(10 / 13), 46.1 \%(6 / 13)$ and $15.3 \%(2 / 13)$ of CD patients with ATD at, respectively, 6-, 12- and 24-month follow-ups on a GFD [149].

Interestingly, a study found that patients with concomitant CD and HT $(n=14)$ needed an almost $50 \%$ higher dose of levothyroxine to reach target thyroid-stimulating hormone (TSH) values when compared to patients with HT alone $(n=68)$ [156]. The authors suggest that this could potentially be explained by reduced absorption of levothyroxine in cases of untreated CD, as an increased need for levothyroxine was prevented by the introduction of a GFD $(n=21)$. However, reduced absorption capacity cannot explain why patients with concomitant HT and CD had significantly higher TSH (5.7 vs. $7.26, p=0.0099)$ and significantly lower free T4 (1.12 vs. $0.01, p<0.0001)$ compared to patients with isolated HT before the initiation of levothyroxine treatment [156]. In accordance with the above, Zubarik et al. [157] reported that patients requiring high doses of levothyroxine to maintain an euthyroid state were more likely to have CD, but this was not confirmed by Sharma et al. [158].

\subsection{Gluten-Related Serology in Autoimmune Thyroid Diseases}

Identified studies measuring levels of IgA-AGA and IgG-AGA in ATDs are summarized in Table 3. Furthermore, a study measuring the presence of IgG antibodies against 125 foods found no difference in IgG positivity for wheat or gliadin between 74 patients with HT and 245 HCs [180], but IgG positivity for barley was significantly higher among patients with HT compared to HCs $(93.2 \%$ vs. $71.0 \%$, $p=8.4 \times 10^{-5}$ ) [180]. Moreover, a study supporting the previously discussed association between CD and an increased need for levothyroxine found that patients treated with high dosage of levothyroxine (125-200 $\mu \mathrm{g} /$ day) had significantly higher levels of IgA-AGA compared to patients receiving low levels of levothyroxine (50-100 $\mu \mathrm{g} /$ day) (medians: 19.69 vs. 13.00, $p=0.033$ ) [162]. 
Table 3. Case-control and cross-sectional cohort studies estimating the prevalence of IgA-AGA and IgG-AGA in patients with ATD and HCs. Results are presented as "number of seropositive individuals"/"number of individuals tested" (\%). AGA: antigliadin antibody, ATD: autoimmune thyroid disease, HCs: healthy controls, Ig: immunoglobulin, NA: not available.

\begin{tabular}{|c|c|c|c|c|c|c|c|c|c|}
\hline Study & $\begin{array}{c}\text { IgA-AGA in } \\
\text { ATD }\end{array}$ & $\begin{array}{c}\text { IgA-AGA in } \\
\text { HCs }\end{array}$ & $p$-Value & $\begin{array}{c}\text { IgG-AGA in } \\
\text { ATD }\end{array}$ & $\begin{array}{c}\text { IgG-AGA in } \\
\text { HCs }\end{array}$ & $p$-Value & $\begin{array}{c}\text { IgA-tTG in } \\
\text { ATD }\end{array}$ & $\begin{array}{c}\text { IgA-tTG in } \\
\text { HCs }\end{array}$ & $p$-Value \\
\hline Ch'ng 2005 [159] & 15/111 (13.5\%) & - & - & - & - & - & $2 / 111(1.8 \%)$ & $1 / 115(0.9 \%)$ & NA \\
\hline Guliter 2007 [160] & - & - & - & - & - & - & $8 / 136(5.8 \%)$ & 1/119 (0.8\%) & $p=0.04$ \\
\hline Hadithi 2007 [161] & 9/104 (8.7\%) & - & - & 7/104 (6.7\%) & - & - & $8 / 104(7.7 \%)$ & - & - \\
\hline Jiskra 2003 [162] & $27 / 169(16.0 \%)$ & $101 / 1312(7.7 \%)$ & $p=0.002$ & $87 / 169(51.5 \%)$ & $92 / 1312(7.0 \%)$ & $p<0.001$ & $25 / 169(14.8 \%)$ & - & - \\
\hline Mainardi 2002 [154] & - & - & - & - & - & - & $2 / 100(2 \%)$ & - & - \\
\hline Mankai 2006 [163] & - & - & - & - & - & - & 6/161 (3.7\%) & - & - \\
\hline Marwaha 2013 [164] & - & - & - & - & - & - & $40 / 577(6.9 \%)$ & $20 / 577(3.5 \%)$ & $p=0.015$ \\
\hline Mehrdad 2012 [165] & $3 / 454(0.7 \%)$ & - & - & - & - & - & $8 / 454(1.8 \%)$ & - & - \\
\hline Meloni 2000 [166] & $13 / 297(4.4 \%)$ & - & - & $18 / 297(6.1 \%)$ & - & - & - & - & - \\
\hline Ravaglia 2003 [167] & - & - & - & $46 / 737(6.2 \%)$ & $7 / 600(1.2 \%)$ & NA & $11 / 737$ (1.5\%) & $2 / 600(0.3 \%)$ & $p=0.046$ \\
\hline Riseh 2017 [168] & $6 / 40(15.0 \%)$ & $5 / 42(11.9 \%)$ & NA & $2 / 40(5.0 \%)$ & $4 / 42(9.5 \%)$ & NA & $9 / 40(22.5 \%)$ & $7 / 42(16.6 \%)$ & NS \\
\hline Sahin 2018 [169] & - & - & - & - & - & - & $3 / 66(4.6 \%)$ & - & - \\
\hline Sari 2009 [170] & - & - & - & - & - & - & 8/101 (7.9\%) & 0/103 (0.0\%) & NA \\
\hline Sattar 2011 [171] & - & - & - & - & - & - & $14 / 302(4.6 \%)$ & - & - \\
\hline Sharma 2016 [158] & - & - & - & - & - & - & $24 / 280(8.6 \%)$ & - & - \\
\hline Spadaccino 2008 [172] & - & - & - & - & - & - & $10 / 271(3.7 \%)$ & - & - \\
\hline Tuhan 2016 [173] & - & - & - & - & - & - & $1 / 80(1.3 \%)$ & - & - \\
\hline Twito 2018 [174] & - & - & - & - & - & - & $5 / 114(4.4 \%)$ & - & - \\
\hline Valentino 2002 [175] & $0 / 14(0.0 \%)$ & - & - & $0 / 14(0.0 \%)$ & - & - & $0 / 14(0.0 \%)$ & - & - \\
\hline Ventura 2014 [176] & - & - & - & - & - & - & $2 / 53(3.8 \%)$ & - & - \\
\hline Volta 2001 [177] & - & - & - & $6 / 220(2.7 \%)$ & $3 / 250(1.2 \%)$ & NA & $7 / 20(3.2 \%)$ & $1 / 250(0.4 \%)$ & $p=0.022$ \\
\hline Zhao 2016 [178] & - & - & - & - & - & - & $26 / 119(21.9 \%)$ & $1 / 102(1.0 \%)$ & $p<0.0001$ \\
\hline Zubarik 2015 [179] & - & - & - & - & - & - & $10 / 499(2.0 \%)$ & - & - \\
\hline
\end{tabular}


An interesting study found that the prevalence of chronic thyroiditis or seropositivity for TPO antibodies was higher among 16 patients with T1D that were seropositive for AGA compared to 37 AGA-seronegative T1D patients (38\% vs. $2.7 \%, p=0.005$ for chronic thyroiditis and $69 \%$ vs. $27 \%, p=$ 0.01 for TPO seropositivity) [181]. This is further supported by a study reporting that the prevalence of tTG $(p=0.023)$ and glutamic acid decarboxylase (GAD) $(p<0.00001)$ antibodies increased with increasing titers of TPO antibodies [164]. A correlation between TPO and IgA-tTG antibodies has also been illustrated in a study suggesting that IgA-tTG may contribute to thyroid dysfunction by binding to thyroid tissue [182]. Similarly, IgG-tTG and IgA-AGA have been found to be predictors of TPO and thyroglobulin antibodies, respectively (IgG-tTG/ TPO: $\beta=0.12,95 \% \mathrm{CI}=(0.03-0.21), p=$ 0.008 , IgA-AGA/thyroglobulin: $\beta=-0.10,95 \% \mathrm{CI}=(-0.19--0.002), p=0.045)$ [168]. The association between ATDs, T1D and CD has been confirmed by additional publications [178,183], including a population-based cohort study concluding that $\mathrm{CD}$ is a risk factor for later development of ATDs among patients with T1D [184].

\subsection{Comorbidity between Celiac Disease and Autoimmune Thyroid Diseases}

A systematic review and meta-analysis of 27 studies calculated the median prevalence of CD in ATDs to be $3.2 \%$, however, a pooled analysis resulted in a prevalence of $1.6 \%(\mathrm{CI}=(1.3-1.9 \%))$ for biopsy-verified CD [185]. The abovementioned low prevalence can possibly be explained by the fact that intestinal biopsies are not performed in all seropositive patients with potential CD. Furthermore, the prevalence of $\mathrm{CD}$ was higher among children with ATDs $(6.2 \%, \mathrm{CI}=(4.0-8.4 \%))$ compared to adults $(2.7 \%, C I=(2.1-3.4))$ [185], whereas another study suggests that the prevalence of $C D$ is higher among patients with ATDs above the age of 65 [167].

A meta-analysis of a systematic review from 2016 revealed a significantly higher prevalence of thyroid disease among patients with $\mathrm{CD}$ compared to controls $(\mathrm{OR}=3.08,95 \% \mathrm{CI}=(2.76-3.56))$ [186] . Similar results were also found for euthyroid ATD $(\mathrm{OR}=4.35,95 \% \mathrm{CI}=(2.88-6.56))$ and hypothyroidism $(\mathrm{OR}=3.38,95 \% \mathrm{CI}=(2.73-4.19))$, however, the prevalence of hyperthyroidism among patients with $\mathrm{CD}$ did not differ from that in controls $(\mathrm{OR}=1.28,95 \% \mathrm{CI}=(0.37-4.46))$ [186]. On the contrary, data from 3209 patients with Grave's disease and 1069 HCs support the idea that the prevalence of CD is higher among patients with Grave's disease (1.1\%) compared to HCs $(0.3 \%)(\mathrm{OR}=3.81,95 \% \mathrm{CI}=(1.17-12.41))$ [187] . Additionally, a meta-analysis reports that the prevalence of biopsy-proven $\mathrm{CD}$ is higher among patients with hyperthyroidism $(2.6 \%, \mathrm{CI}=(0.7-4.4 \%))$ compared to patients with hypothyroidism $(1.4 \%, \mathrm{CI}=$ $(1.0-1.9 \%))$ [185]. We hypothesize that the late age of disease onset for hyperthyroidism could be a potential explanation for the above contradictive results. An association between thyroid disease and CD has also been confirmed by more recent studies [188,189]. One calculated that the prevalence of thyroid disease was fourfold higher among 288 patients with untreated CD compared to 250 controls without CD $(13.6 \%$ vs. $3.2 \%, p<0.05)$ [188] and the other calculated the hazard ratio of subsequent hypothyroidism among patients with CD to be $4.64(95 \% \mathrm{CI}=(2.88-7.46))$ [189].

It has been debated whether the late diagnosis of $C D$ and, as a result, the late introduction of a GFD can increase the risk of developing other autoimmune diseases $[55,102,103,190]$. When a meta-analysis compared treated and untreated patients with $C D$, no difference was found in the frequency of thyroid disease $(\mathrm{OR}=1.08,95 \% \mathrm{CI}=(0.61-1.92))$ [186]. In addition, a study highlights that first-degree relatives of patients with CD also have an increased risk of ATDs [191]. Interestingly, a study reports that the prevalence of ATDs among Irish women with CD has decreased significantly over recent decades [192], whereas another study suggests that the prevalence of autoimmune thyroiditis may be higher among seronegative $(26.9 \%)$ compared to seropositive $(9.7 \%)$ patients with CD $(p=0.002)$ [193]. Last, but not least, the prevalence of ATDs has also been reported to be high among patients with non-celiac gluten/wheat sensitivity [194,195] and dermatitis herpetiformis [196]. 


\section{Conclusions}

The current level of evidence is yet not sufficient to recommend a GFD to patients with MS, psoriasis, T1D or ATDs. Larger epidemiological studies and meta-analyses of systematic reviews support that psoriasis, T1D and ATDs are all associated with CD, but this does not seem to be the case for MS. The only clinical trial to have studied the effects of a GFD among patients with MS found positive results on important MS-specific outcomes, however, the publication was subject to major limitations. Further studies are warranted to replicate the results found by Rodrigo et al. [31] and clarify whether any beneficial effects could be restricted to specific subgroups of patients. With regard to psoriasis, the currently available data suggest that patients with gluten-related antibodies or CD may benefit from a GFD, however, larger trials are still missing. The majority of studies failed to reveal an effect of a GFD on diabetes-related autoantibodies, however, it seems likely that a GFD may contribute to normalizing metabolic control in patients with T1D. In addition, some publications report that untreated CD can affect metabolic control and diabetic complications in patients with T1D. On the contrary, studies support the idea that thyroid-related antibodies may respond to a GFD in patients with concomitant CD and ATD, however, no studies have addressed the effects of a GFD among non-celiac patients with ATDs to date. Lastly, in patients with concomitant CD and ATD, a GFD may improve the absorption of levothyroxine.

Author Contributions: Conceptualization, M.P., J.C.A., J.L.F. and K.J.; methodology, M.P., J.C.A. and K.J.; writing—original draft preparation, M.P., J.C.A. and K.J.; writing—review and editing, M.P., J.C.A., J.L.F. and K.J.; visualization, M.P. and K.J., funding acquisition, M.P., J.C.A. and J.L.F. All authors have read and agreed to the published version of the manuscript.

Funding: This article was supported by Scleroseforeningen (the Danish Multiple Sclerosis Society), as well as Kirsten and Freddy Johansen's foundation.

Conflicts of Interest: The authors declare no conflict of interest in relation to this paper. The funders had no role in the design of the study; in the collection, analyses, or interpretation of data; in the writing of the manuscript, or in the decision to publish the results. 


\section{Appendix A}

Table A1. Metabolic control and effects of a GFD in patients with concomitant T1D and CD. CD: celiac Disease, GFD: gluten-free diet, NS: not significant, T1D: type 1 diabetes.

\begin{tabular}{|c|c|c|c|c|c|c|}
\hline Study & Sample Size & Study Design & HbA1c & Insulin Dose & Diabetic Complications & $\begin{array}{l}\text { Hypoglycemic } \\
\text { Episodes }\end{array}$ \\
\hline Abid 2011 [121] & $22 \mathrm{CD}$ and T1D & $\begin{array}{l}\text { before vs. after } 1 \text { year } \\
\text { on GFD }\end{array}$ & NS & $\begin{array}{l}\text { before vs. after GFD: } \\
0.88 \text { vs. } 1.1, p<0.005\end{array}$ & - & $\begin{array}{l}\text { before vs. after GFD: } \\
\text { Eight }(36 \%) \text { vs. two } \\
(9 \%), p<0.07\end{array}$ \\
\hline Acerini 1998 [122] & Seven CD and T1D & $\begin{array}{c}\text { before vs. after } 2 \text { years } \\
\text { on GFD }\end{array}$ & NS trend & NS & - & - \\
\hline Amin 2002 [123] & $\begin{array}{l}11 \text { CD and T1D vs. } 22 \\
\text { with T1D only }\end{array}$ & $\begin{array}{l}\text { before vs. after } 1 \text { year } \\
\text { on GFD and } \\
\text { comparison with } \\
\text { patients with T1D only }\end{array}$ & $\begin{array}{l}\text { CD and T1D vs. T1D } \\
\text { only: } 8.9 \pm 0.3 \text { vs. } 9.8 \pm \\
0.3, p=0.002 ; \text { before vs. } \\
\text { after GFD: } 8.9 \pm 0.1 \text { vs. } \\
8.3 \pm 0.1, p=0.002 ; \text { CD } \\
\text { and T1D after GFD vs. } \\
\text { T1D only: } 8.3 \pm 0.2 \text { vs. } \\
10.0 \pm 0.2 \%, p=0.02\end{array}$ & $\begin{array}{l}\text { NS between groups; } \\
\text { increased in both } \\
\text { groups at follow-up }\end{array}$ & - & - \\
\hline Bakker 2013 [124] & $\begin{array}{l}31 \text { CD and T1D vs. } 46 \\
\text { with T1D only }\end{array}$ & $\begin{array}{l}\text { before vs. after GFD } \\
\text { and comparison with } \\
\text { patients with T1D only }\end{array}$ & $\begin{array}{l}\text { NS (CD and T1D vs. T1D } \\
\text { only and before vs. after } \\
\text { GFD) }\end{array}$ & $\begin{array}{l}\text { NS (CD and T1D vs. } \\
\text { T1D only) }\end{array}$ & $\begin{array}{c}\text { protective role of } \\
\text { concurrent (treated) CD } \\
\text { against retinopathy }\end{array}$ & - \\
\hline $\begin{array}{l}\text { Fröhlich-Reiterer } 2011 \\
\text { [125] }\end{array}$ & $\begin{array}{l}411 \mathrm{CD} \text { and T1D vs. } \\
17661 \text { with T1D only }\end{array}$ & $\begin{array}{l}\text { CD and T1D vs. T1D } \\
\text { only }\end{array}$ & NS & NS & NS & NS \\
\hline Goh 2010 [126] & $\begin{array}{l}29 \text { CD and T1D vs. } 58 \\
\text { with T1D only }\end{array}$ & $\begin{array}{c}\text { evaluation every } 6 \\
\text { months from } 1 \text { year } \\
\text { prior to CD diagnosis to } \\
1 \text { year after }\end{array}$ & $\begin{array}{l}\text { NS, similar between } \\
\text { groups throughout the } \\
\text { study }\end{array}$ & - & - & - \\
\hline Hansen 2006 [127] & $31 \mathrm{CD}$ and T1D & $\begin{array}{c}\text { before vs. after } 2 \text { years } \\
\text { on GFD }\end{array}$ & NS & - & - & - \\
\hline Kaspers 2004 [128] & $\begin{array}{c}127 \text { with CD and T1D } \\
\text { vs. } 19796 \text { with T1D } \\
\text { only }\end{array}$ & $\begin{array}{l}\text { CD and T1D vs. T1D } \\
\text { only }\end{array}$ & $\begin{array}{c}\text { CD and T1D vs. T1D } \\
\text { only: } 8.1 \pm 1.8 \% \text { vs. } 8.8 \pm \\
2.4 \%, p<0.001\end{array}$ & NS & - & NS \\
\hline
\end{tabular}


Table A1. Cont.

\begin{tabular}{|c|c|c|c|c|c|c|}
\hline Study & Sample Size & Study Design & HbA1c & Insulin Dose & Diabetic Complications & $\begin{array}{l}\text { Hypoglycemic } \\
\text { Episodes }\end{array}$ \\
\hline Kaur 2020 [129] & $30 \mathrm{CD}$ and $\mathrm{T} 1 \mathrm{D}$ & $\begin{array}{c}\text { prospective } \\
\text { randomized controlled } \\
\text { trial (1 year on GFD vs. } \\
\text { normal diet) }\end{array}$ & $\begin{array}{l}\text { NS between groups, } \\
\text { lower after GFD (within } \\
\text { group, } p<0.05 \text { ) }\end{array}$ & NS & - & $\begin{array}{c}\text { NS between groups, } \\
\text { lower after GFD } \\
\text { (within group, } p= \\
0.03 \text { ) }\end{array}$ \\
\hline Kaukinen 1999 [130] & $\begin{array}{c}22 \mathrm{CD} \text { and T1D vs. } 22 \\
\text { with T1D only }\end{array}$ & $\begin{array}{l}\text { retrospective and } \\
\text { prospective study }\end{array}$ & NS & NS & - & - \\
\hline Leeds 2011 [131] & $\begin{array}{l}41 \mathrm{CD} \text { and T1D vs. } 41 \\
\text { with T1D only }\end{array}$ & $\begin{array}{l}\text { before vs. after } 1 \text { year } \\
\text { on GFD and } \\
\text { comparison with } \\
\text { patients with T1D only }\end{array}$ & $\begin{array}{c}\text { CD and T1D vs. T1D } \\
\text { only: } 8.2 \text { vs. } 7.5 \%, p= \\
0.05 \text {; before vs. after GFD: } \\
\text { improved among } \\
\text { compliant patients ( } n=9, \\
\text { NS) }\end{array}$ & NS & $\begin{array}{l}\text { CD and T1D vs. T1D only: } \\
\text { retinopathy: } 58.3 \text { vs. } 25 \%, p \\
=0.02 ; \text { nephropathy: } 41.6 \\
\text { vs. } 4.2 \%, p=0.009 ; \\
\text { peripheral neuropathy: } \\
41.6 \text { vs. } 16.6 \%, p=0.11 ; \text { NS } \\
\text { reduction in advanced } \\
\text { nephropathy after GFD }\end{array}$ & - \\
\hline Mohn 2001 [132] & $\begin{array}{c}18 \mathrm{CD} \text { and T1D vs. } 26 \\
\text { with T1D only }\end{array}$ & $\begin{array}{l}\text { evaluation every } 6 \\
\text { months from } 18 \text { months } \\
\text { prior to CD diagnosis to } \\
18 \text { months after }\end{array}$ & NS & $\begin{array}{c}\text { NS prior to CD } \\
\text { diagnosis; at CD } \\
\text { diagnosis: CD and } \\
\text { T1D vs. T1D only: } 0.6 \\
\pm 0.2 \text { vs. } 0.9 \pm 0.3, p= \\
0.05 ; \text { increased after } \\
\text { GFD }\end{array}$ & - & $\begin{array}{c}\mathrm{CD} \text { and T1D vs. T1D } \\
\text { only at }+/-6 \text { months } \\
\text { from CD diagnosis: } \\
4.5 \pm 4 \text { vs. } 2.0 \pm 2.2, p \\
=0.01\end{array}$ \\
\hline Narula 2009 [133] & $\begin{array}{l}22 \mathrm{CD} \text { and T1D vs. } 50 \\
\text { with T1D only }\end{array}$ & $\begin{array}{l}\text { before vs. after } 1 \text { year } \\
\text { on GFD for eight } \\
\text { complaint patients and } \\
\text { comparison with } \\
\text { patients with T1D only }\end{array}$ & - & $\begin{array}{l}\text { NS increase after } \\
\text { GFD; NS difference in } \\
\text { change of insulin } \\
\text { requirement }\end{array}$ & - & - \\
\hline $\begin{array}{c}\text { Pham-Short } 2013 \\
\text { [134] }\end{array}$ & $\begin{array}{l}129 \mathrm{CD} \text { and T1D vs. } \\
2510 \text { with T1D only }\end{array}$ & $\begin{array}{l}\text { CD and T1D vs. T1D } \\
\text { only; compliant vs. } \\
\text { non-compliant to GFD }\end{array}$ & $\begin{array}{c}\text { CD and T1D vs. T1D } \\
\text { only: } 8.3(7.6-9.3) \text { vs. } 8.6 \\
(7.7-9.6), p=0.04 ; \\
\text { compliant vs. } \\
\text { non-compliant: } 8.2 \\
\text { (7.6-9.0) vs. } 8.7(7.8-10.0), \\
p=0.003\end{array}$ & $\begin{array}{l}\text { CD and T1D vs. T1D } \\
\text { only: } 1.08(0.91-1.34) \\
\text { vs. } 1.05(0.87-1.28), p \\
=0.08 ; \text { compliant vs. } \\
\text { non-compliant: } 1.03 \\
(0.88-1.27) \text { vs. } 1.15 \\
(0.99-1.46), p=0.002\end{array}$ & $\begin{array}{l}\text { elevated albumin excretion } \\
\text { rate: compliant vs. } \\
\text { non-compliant: } 23 \text { vs. } 40 \% \text {, } \\
p=0.04 ; \text { CD and T1D vs. } \\
\text { T1D only: NS; retinopathy, } \\
\text { peripheral nerve and } \\
\text { pupillary abnormality: NS }\end{array}$ & - \\
\hline
\end{tabular}


Table A1. Cont.

\begin{tabular}{|c|c|c|c|c|c|c|}
\hline Study & Sample Size & Study Design & HbA1c & Insulin Dose & Diabetic Complications & $\begin{array}{l}\text { Hypoglycemic } \\
\text { Episodes }\end{array}$ \\
\hline Poulain 2007 [135] & $15 \mathrm{CD}$ and T1D & before vs. after GFD & NS & $\begin{array}{c}\text { before vs. after GFD: } \\
0.9 \pm 0.2 \text { vs. } 1.0 \pm 0.4 \\
p=0.05\end{array}$ & - & - \\
\hline Rami 2005 [136] & $\begin{array}{l}98 \mathrm{CD} \text { and T1D vs. } \\
195 \text { with T1D only }\end{array}$ & $\begin{array}{l}\text { CD and T1D vs. T1D } \\
\text { only at diagnosis of } \\
\text { T1D, diagnosis of CD } \\
\text { and follow-up }\end{array}$ & NS & NS & - & NS \\
\hline $\begin{array}{c}\text { Sanchez-Albisua } 2005 \\
\text { [137] }\end{array}$ & Five $\mathrm{CD}$ and T1D & before vs. after GFD & $\begin{array}{l}\text { before vs. after GFD:8.0 } \\
\text { vs. } 7.3, p=0.05\end{array}$ & - & - & $\begin{array}{l}\text { improved in two out } \\
\text { of five compliant } \\
\text { patients }\end{array}$ \\
\hline Saukkonen 2002 [138] & $18 \mathrm{CD}$ and $\mathrm{T} 1 \mathrm{D}$ & before vs. after GFD & NS & - & - & - \\
\hline Sun 2009 [139] & $\begin{array}{l}49 \mathrm{CD} \text { and T1D vs. } 49 \\
\text { with T1D only }\end{array}$ & $\begin{array}{l}\text { CD and T1D vs. T1D } \\
\text { only prior to and at } \\
\text { diagnosis of CD as well } \\
\text { as after } 1 \text { and } 2 \text { years on } \\
\text { GFD }\end{array}$ & $\begin{array}{l}\text { CD and T1D vs. T1D } \\
\text { only: prior to and at } \\
\text { diagnosis of CD: } \\
\text { significantly lower in CD } \\
\text { and T1D; NS after GFD }\end{array}$ & NS & - & - \\
\hline Saadah 2004 [140] & $\begin{array}{c}21 \mathrm{CD} \text { and T1D vs. } 42 \\
\text { with T1D only }\end{array}$ & $\begin{array}{l}\text { before vs. after } 1 \text { year } \\
\text { on GFD and } \\
\text { comparison with } \\
\text { patients with T1D only }\end{array}$ & $\begin{array}{c}\text { CD and T1D vs. T1D } \\
\text { only: NS; before vs. after } \\
\text { GFD: NS }\end{array}$ & $\begin{array}{l}\text { CD and T1D vs. T1D } \\
\text { only: lower in CD } \\
\text { and T1D prior to GFD } \\
(p=0.054) ; \text { NS after } \\
\text { GFD }\end{array}$ & - & - \\
\hline Valetta 2007 [141] & $\begin{array}{c}27 \mathrm{CD} \text { and T1D vs. } 43 \\
\text { with T1D only }\end{array}$ & $\begin{array}{c}\text { CD and T1D vs. T1D } \\
\text { only at diagnosis of CD } \\
\text { as well as after } 1 \text { and } 2 \\
\text { years on GFD }\end{array}$ & NS & NS & - & - \\
\hline Westman 1999 [142] & $\begin{array}{c}20 \text { CD and T1D vs. } 40 \\
\text { with T1D only }\end{array}$ & $\begin{array}{l}\text { CD and T1D vs. T1D } \\
\text { only; compliant vs. } \\
\text { non-compliant to GFD }\end{array}$ & NS & - & - & - \\
\hline
\end{tabular}




\section{References}

1. Niland, B.; Cash, B.D. Health Benefits and Adverse Effects of a Gluten-Free Diet in Non-Celiac Disease Patients. Gastroenterol. Hepatol. 2018, 14, 82-91.

2. Lebwohl, B.; Sanders, D.S.; Green, P.H.R. Coeliac disease. Lancet 2018, 391, 70-81. [CrossRef]

3. Mokarizadeh, A.; Esmaeili, P.; Soraya, H.; Hassanzadeh, K.; Jalili, A.; Abdi, M.; Faryabi, M.R. Antibody against $\alpha$-gliadin 33-mer peptide: Is the key initiating factor for development of multiple sclerosis during gluten sensitivity? J. Med. Hypotheses Ideas 2015, 9, 38-44. [CrossRef]

4. Lerner, A.; Shoenfeld, Y.; Matthias, T. Adverse effects of gluten ingestion and advantages of gluten withdrawal in nonceliac autoimmune disease. Nutr. Rev. 2017, 75, 1046-1058. [CrossRef] [PubMed]

5. Perlmutter, D.; Loberg, K. Grain Brain: The Surprising Truth about Wheat, Carbs, and Sugar-Your Brain's Silent Killers; Little, Brown and Company Hachette Book Group: New York, NY, USA, 2013; ISBN 9780316234801.

6. Afifi, L.; Danesh, M.J.; Lee, K.M.; Beroukhim, K.; Farahnik, B.; Ahn, R.S.; Yan, D.; Singh, R.K.; Nakamura, M.; Koo, J.; et al. Dietary Behaviors in Psoriasis: Patient-Reported Outcomes from a U.S. National Survey. Dermatol. Ther. 2017, 7, 227-242. [CrossRef] [PubMed]

7. Fitzgerald, K.C.; Tyry, T.; Salter, A.; Cofield, S.S.; Cutter, G.; Fox, R.J.; Marrie, R.A. A survey of dietary characteristics in a large population of people with multiple sclerosis. Mult. Scler. Relat. Disord. 2018, 22, 12-18. [CrossRef] [PubMed]

8. Leong, E.M.; Semple, S.J.; Angley, M.; Siebert, W.; Petkov, J.; McKinnon, R.A. Complementary and alternative medicines and dietary interventions in multiple sclerosis: What is being used in South Australia and why? Complement. Ther. Med. 2009, 17, 216-223. [CrossRef]

9. Shewry, P.R. Wheat. J. Exp. Bot. 2009, 60, 1537-1553. [CrossRef]

10. Koehler, P.; Wieser, H.; Konitzer, K. Gluten-The Precipitating Factor. In Celiac Disease and Gluten; Elsevier Inc.: San Diego, CA, USA, 2014; pp. 97-148.

11. Velísek, J. Amino Acids, Peptides and Proteins. In The Chemistry of Food; WILEY Blackwell: Hoboken, NJ, USA, 2014; pp. 60-61.

12. Belitz, H.-D.; Grosch, W.; Schieberle, P. Cereals and Cereal Products. In Food Chemistry, 4th ed; Belitz, H.-D., Grosch, W., Schieberle, P., Eds.; Springer: Berlin/Heidelberg, Germany, 2009; pp. 670-745.

13. Schalk, K.; Lexhaller, B.; Koehler, P.; Scherf, K.A. Isolation and characterization of gluten protein types from wheat, rye, barley and oats for use as reference materials. PLoS ONE 2017, 12, e0172819. [CrossRef]

14. Scherf, K.A.; Koehler, P.; Wieser, H. Gluten and wheat sensitivities-An overview. J. Cereal Sci. 2016, 67, 2-11. [CrossRef]

15. Codex Alimentarius International Food Standards. Standard for Foods for Special Dietary Use for Persons Intolerant to Gluten Codex Stan 118-1979; 2008; pp. 1-5. Available online: https://www.google.com/url?sa=t\&rct=j\&q=\&esrc=s\&source=web\&cd=\&cad=rja\&uact=8\&ved= 2ahUKEwjj6ZPvxvjqAhXpkYsKHQ45DPUQFjAAegQIBRAB\&url=http\%3A\%2F\%2Fwww.fao.org\% 2Finput\%2Fdownload\%2Fstandards\%2F291\%2FCXS_118e_2015.pdf\&usg=AOvVaw3j2IOMnRs176g2GNtOyUH (accessed on 1 August 2020).

16. Wieser, H. Chemistry of gluten proteins. Food Microbiol. 2007, 24, 115-119. [CrossRef] [PubMed]

17. Sander, G.R.; Cummins, A.G.; Henshall, T.; Powell, B.C. Rapid disruption of intestinal barrier function by gliadin involves altered expression of apical junctional proteins. FEBS Lett. 2005, 579, 4851-4855. [CrossRef] [PubMed]

18. Drago, S.; El Asmar, R.; Di Pierro, M.; Grazia Clemente, M.; Tripathi, A.; Sapone, A.; Thakar, M.; Iacono, G.; Carroccio, A.; D'Agate, C.; et al. Gliadin, zonulin and gut permeability: Effects on celiac and non-celiac intestinal mucosa and intestinal cell lines. Scand. J. Gastroenterol. 2006, 41, 408-419. [CrossRef] [PubMed]

19. Hollon, J.; Puppa, E.L.; Greenwald, B.; Goldberg, E.; Guerrerio, A.; Fasano, A. Effect of gliadin on permeability of intestinal biopsy explants from celiac disease patients and patients with non-celiac gluten sensitivity. Nutrients 2015, 7, 1565-1576. [CrossRef]

20. Lammers, K.M.; Lu, R.; Brownley, J.; Lu, B.; Gerard, C.; Thomas, K.; Rallabhandi, P.; Shea-Donohue, T.; Tamiz, A.; Alkan, S.; et al. Gliadin induces an increase in intestinal permeability and zonulin release by binding to the chemokine receptor CXCR3. Gastroenterology 2008, 135, 194.e3-204.e3. [CrossRef] 
21. Tripathi, A.; Lammers, K.M.; Goldblum, S.; Shea-Donohue, T.; Netzel-Arnett, S.; Buzza, M.S.; Antalis, T.M.; Vogel, S.N.; Zhao, A.; Yang, S.; et al. Identification of human zonulin, a physiological modulator of tight junctions, as prehaptoglobin-2. Proc. Natl. Acad. Sci. USA 2009, 106, 16799-16804. [CrossRef]

22. Sapone, A.; de Magistris, L.; Pietzak, M.; Clemente, M.G.; Tripathi, A.; Cucca, F.; Lampis, R.; Kryszak, D.; Cartenì, M.; Generoso, M.; et al. Zonulin upregulation is associated with increased gut permeability in subjects with type 1 diabetes and their relatives. Diabetes 2006, 55, 1443-1449. [CrossRef]

23. Aydin, B.K.; Yildiz, M.; Akgun, A.; Topal, N.; Adal, E.; Onal, H. Children with Hashimoto's Thyroiditis Have Increased Intestinal Permeability: Results of a Pilot Study. J. Clin. Res. Pediatric Endocrinol. 2020. [CrossRef]

24. Caviglia, G.P.; Dughera, F.; Ribaldone, D.G.; Rosso, C.; Abate, M.L.; Pellicano, R.; Bresso, F.; Smedile, A.; Saracco, G.M.; Astegiano, M. Serum zonulin in patients with inflammatory bowel disease: A pilot study. Minerva Med. 2019, 110, 95-100. [CrossRef]

25. Fasano, A. All disease begins in the (leaky) gut: Role of zonulin-mediated gut permeability in the pathogenesis of some chronic inflammatory diseases. F1000 Res. 2020, 9. [CrossRef]

26. Ajamian, M.; Steer, D.; Rosella, G.; Gibson, P.R. Serum zonulin as a marker of intestinal mucosal barrier function: May not be what it seems. PLoS ONE 2019, 14, e0210728. [CrossRef] [PubMed]

27. Scheffler, L.; Crane, A.; Heyne, H.; Tönjes, A.; Schleinitz, D.; Ihling, C.H.; Stumvoll, M.; Freire, R.; Fiorentino, M.; Fasano, A.; et al. Widely Used Commercial ELISA Does Not Detect Precursor of Haptoglobin2, but Recognizes Properdin as a Potential Second Member of the Zonulin Family. Front. Endocrinol. 2018, 9, 22. [CrossRef] [PubMed]

28. Hernandez, A.L.; O'Connor, K.C.; Hafler, D.A. Multiple Sclerosis. In The Autoimmune Diseases, 5th ed.; Rose, R.N., Mackay, R.I., Eds.; Elsevier Inc.: San Diego, CA, USA, 2014; pp. 735-756.

29. Beckett, J.M.; Bird, M.-L.; Pittaway, J.K.; Ahuja, K.D. Diet and Multiple Sclerosis: Scoping Review of Web-Based Recommendations. Interact. J. Med. Res. 2019, 8, e10050. [CrossRef] [PubMed]

30. Brenton, J.N.; Goldman, M.D. A study of dietary modification: Perceptions and attitudes of patients with multiple sclerosis. Mult. Scler. Relat. Disord. 2016, 8, 54-57. [CrossRef] [PubMed]

31. Rodrigo, L.; Hernández-Lahoz, C.; Fuentes, D.; Mauri, G.; Alvarez, N.; Vega, J.; González, S. Randomised Clinical Trial Comparing the Efficacy of A Gluten-Free Diet Versus A Regular Diet in A Series of Relapsing-Remitting Multiple Sclerosis Patients. Int. J. Neurol. Neurother. 2014, 1. [CrossRef]

32. Irish, A.K.; Erickson, C.M.; Wahls, T.L.; Snetselaar, L.G.; Darling, W.G. Randomized control trial evaluation of a modified Paleolithic dietary intervention in the treatment of relapsing-remitting multiple sclerosis: A pilot study. Degener. Neurol. Neuromuscul. Dis. 2017, 7, 1-18. [CrossRef]

33. Lee, J.E.; Bisht, B.; Hall, M.J.; Rubenstein, L.M.; Louison, R.; Klein, D.T.; Wahls, T.L. A Multimodal, Nonpharmacologic Intervention Improves Mood and Cognitive Function in People with Multiple Sclerosis. J. Am. Coll. Nutr. 2017, 36, 150-168. [CrossRef]

34. Maxwell, K.F.; Wahls, T.; Browne, R.W.; Rubenstein, L.; Bisht, B.; Chenard, C.A.; Snetselaar, L.; Weinstock-Guttman, B.; Ramanathan, M. Lipid profile is associated with decreased fatigue in individuals with progressive multiple sclerosis following a diet-based intervention: Results from a pilot study. PLoS ONE 2019, 14, e0218075.

35. Bisht, B.; Darling, W.G.; Shivapour, E.T.; Lutgendorf, S.K.; Snetselaar, L.G.; Chenard, C.A.; Wahls, T.L. Multimodal intervention improves fatigue and quality of life in subjects with progressive multiple sclerosis: A pilot study. Degener. Neurol. Neuromuscul. Dis. 2015, 5, 19-35.

36. Thompson, A.J.; Baranzini, S.E.; Geurts, J.; Hemmer, B.; Ciccarelli, O. Multiple sclerosis. Lancet 2018, 391, 1622-1636. [CrossRef]

37. Banati, M.; Csecsei, P.; Koszegi, E.; Nielsen, H.H.; Suto, G.; Bors, L.; Trauninger, A.; Csepany, T.; Rozsa, C.; Jakab, G.; et al. Antibody response against gastrointestinal antigens in demyelinating diseases of the central nervous system. Eur. J. Neurol. 2013, 20, 1492-1495. [CrossRef] [PubMed]

38. Borhani Haghighi, A.; Ansari, N.; Mokhtari, M.; Geramizadeh, B.; Lankarani, K.B. Multiple sclerosis and gluten sensitivity. Clin. Neurol. Neurosurg. 2007, 109, 651-653. [CrossRef] [PubMed]

39. Nicoletti, A.; Patti, F.; Lo Fermo, S.; Sciacca, A.; Laisa, P.; Liberto, A.; Lanzafame, S.; Contraffatto, D.; D'Agate, C.; Russo, A.; et al. Frequency of celiac disease is not increased among multiple sclerosis patients. Mult. Scler. J. 2008, 14, 698-700. [CrossRef] [PubMed]

40. Pengiran Tengah, C.D.S.N.A.; Lock, R.J.; Unsworth, D.J.; Wills, A.J. Multiple sclerosis and occult gluten sensitivity. Neurology 2004, 62, 2326-2327. [CrossRef] [PubMed] 
41. Ahmadabadi, F.B.; Shahbazkhani, B.; Tafakhori, A.; Khosravi, A.; Mashhadi, M.M. A genetic study of celiac disease in patients with multiple sclerosis in comparison with celiac patients and healthy controls. Govaresh 2018, 22, 256-260.

42. Shor, D.B.-A.; Barzilai, O.; Ram, M.; Izhaky, D.; Porat-Katz, B.S.; Chapman, J.; Blank, M.; Anaya, J.-M.; Shoenfeld, Y. Gluten Sensitivity in Multiple Sclerosis. Ann. N. Y. Acad. Sci. 2009, 1173, 343-349. [CrossRef]

43. Sánchez, D.; Tucková, L.; Sebo, P.; Michalak, M.; Whelan, A.; Sterzl, I.; Jelínková, L.; Havrdová, E.; Imramovská, M.; Benes, Z.; et al. Occurrence of IgA and IgG autoantibodies to calreticulin in coeliac disease and various autoimmune diseases. J. Autoimmun. 2000, 15, 441-449. [CrossRef]

44. Reichelt, K.-L.; Jensen, D. IgA antibodies against gliadin and gluten in multiple sclerosis. Acta Neurol. Scand. 2004, 110, 239-241. [CrossRef]

45. Roth, E.B.; Bodil Roth, E.; Theander, E.; Londos, E.; Sandberg-Wollheim, M.; Larsson, A.; Sjöberg, K.; Stenberg, P. Pathogenesis of Autoimmune Diseases: Antibodies Against Transglutaminase, Peptidylarginine Deiminase and Protein-bound Citrulline in Primary Sjögren's Syndrome, Multiple Sclerosis and Alzheimer's Disease. Scand. J. Immunol. 2008, 67, 626-631. [CrossRef]

46. de Oliveira, P.; de Carvalho, D.R.; Brandi, I.V.; Pratesi, R. Serological prevalence of celiac disease in Brazilian population of multiple sclerosis, neuromyelitis optica and myelitis. Mult. Scler. Relat. Disord. 2016, 9, 125-128. [CrossRef]

47. Khoshbaten, M.; Farhoudi, M.; Nikanfar, M.; Ayromlou, H.; Shaafi, S.; Sadreddini, S.A.; Pashapoor, A.; Taheraghdam, A.; Yazdchi, M.; Sharifi, N. Celiac disease and multiple sclerosis in the northwest of Iran. Bratisl. Lek. Listy 2012, 113, 495-497. [CrossRef] [PubMed]

48. Salvatore, S.; Finazzi, S.; Ghezzi, A.; Tosi, A.; Barassi, A.; Luini, C.; Bettini, B.; Zibetti, A.; Nespoli, L.; Melzi d'Eril, G.V. Multiple sclerosis and celiac disease: Is there an increased risk? Mult. Scler. 2004, 10, 711-712. [CrossRef] [PubMed]

49. Aboud, R.S.; Ismael, M.K.; Mohammed, H.J. Detection of Human Leukocyte Antigen and Celiac Disease Auto Antibodies in serum of Patients with Multiple Sclerosis. Iraqi J. Sci. 2014, 55, 1477-1483.

50. Rodrigo, L.; Hernández-Lahoz, C.; Fuentes, D.; Alvarez, N.; López-Vázquez, A.; González, S. Prevalence of celiac disease in multiple sclerosis. BMC Neurol. 2011, 11. [CrossRef]

51. Thomsen, H.L.; Jessen, E.B.; Passali, M.; Frederiksen, J.L. The role of gluten in multiple sclerosis: A systematic review. Mult. Scler. Relat. Disord. 2019, 27, 156-163. [CrossRef]

52. Eaton, W.W.; Rose, N.R.; Kalaydjian, A.; Pedersen, M.G.; Mortensen, P.B. Epidemiology of autoimmune diseases in Denmark. J. Autoimmun. 2007, 29, 1-9. [CrossRef]

53. Grode, L.; Bech, B.H.; Jensen, T.M.; Humaidan, P.; Agerholm, I.E.; Plana-Ripoll, O.; Ramlau-Hansen, C.H. Prevalence, incidence, and autoimmune comorbidities of celiac disease: A nation-wide, population-based study in Denmark from 1977 to 2016. Eur. J. Gastroenterol. Hepatol. 2018, 30, 83-91. [CrossRef]

54. Ludvigsson, J.F.; Olsson, T.; Ekbom, A.; Montgomery, S.M. A population-based study of coeliac disease, neurodegenerative and neuroinflammatory diseases. Aliment. Pharmacol. Ther. 2007, 25, 1317-1327. [CrossRef]

55. Cosnes, J.; Cellier, C.; Viola, S.; Colombel, J.-F.; Michaud, L.; Sarles, J.; Hugot, J.-P.; Ginies, J.-L.; Dabadie, A.; Mouterde, O.; et al. Incidence of autoimmune diseases in celiac disease: Protective effect of the gluten-free diet. Clin. Gastroenterol. Hepatol. 2008, 6, 753-758. [CrossRef]

56. Escudié, J.-B.; Rance, B.; Malamut, G.; Khater, S.; Burgun, A.; Cellier, C.; Jannot, A.-S. A novel data-driven workflow combining literature and electronic health records to estimate comorbidities burden for a specific disease: A case study on autoimmune comorbidities in patients with celiac disease. BMC Med. Inform. Decis. Mak. 2017, 17, 140. [CrossRef]

57. Foulon, S.; Maura, G.; Dalichampt, M.; Alla, F.; Debouverie, M.; Moreau, T.; Weill, A. Prevalence and mortality of patients with multiple sclerosis in France in 2012: A study based on French health insurance data. J. Neurol. 2017, 264, 1185-1192. [CrossRef] [PubMed]

58. Birlea, S.A.; Serota, M.; Norris, D.A. Nonbullous Skin Diseases: Alopecia Areata, Vitiligo, Psoriasis, and Urticaria. Autoimmune Dis. 2020, 1211-1234. [CrossRef]

59. Ford, A.R.; Siegel, M.; Bagel, J.; Cordoro, K.M.; Garg, A.; Gottlieb, A.; Green, L.J.; Gudjonsson, J.E.; Koo, J.; Lebwohl, M.; et al. Dietary Recommendations for Adults With Psoriasis or Psoriatic Arthritis From the Medical Board of the National Psoriasis Foundation: A Systematic Review. JAMA Dermatol. 2018, 154, 934-950. [CrossRef] [PubMed] 
60. Drucker, A.M.; Qureshi, A.A.; Thompson, J.M.; Li, T.; Cho, E. Gluten intake and risk of psoriasis, psoriatic arthritis, and atopic dermatitis among United States women. J. Am. Acad. Dermatol. 2020, 82, 661-665. [CrossRef] [PubMed]

61. Michaëlsson, G.; Gerdén, B.; Hagforsen, E.; Nilsson, B.; Pihl-Lundin, I.; Kraaz, W.; Hjelmquist, G.; Lööf, L. Psoriasis patients with antibodies to gliadin can be improved by a gluten-free diet. Br. J. Dermatol. 2000, 142, 44-51. [CrossRef]

62. Michaëlsson, G.; Ahs, S.; Hammarström, I.; Lundin, I.P.; Hagforsen, E. Gluten-free diet in psoriasis patients with antibodies to gliadin results in decreased expression of tissue transglutaminase and fewer Ki67 + cells in the dermis. Acta Derm. Venereol. 2003, 83, 425-429. [PubMed]

63. Michaëlsson, G.; Kristjánsson, G.; Pihl Lundin, I.; Hagforsen, E. Palmoplantar pustulosis and gluten sensitivity: A study of serum antibodies against gliadin and tissue transglutaminase, the duodenal mucosa and effects of gluten-free diet. Br. J. Dermatol. 2007, 156, 659-666. [CrossRef]

64. Kolchak, N.A.; Tetarnikova, M.K.; Theodoropoulou, M.S.; Michalopoulou, A.P.; Theodoropoulos, D.S. Prevalence of antigliadin IgA antibodies in psoriasis vulgaris and response of seropositive patients to a gluten-free diet. J. Multidiscip. Healthc. 2018, 11, 13-19. [CrossRef]

65. De Bastiani, R.; Gabrielli, M.; Lora, L.; Napoli, L.; Tosetti, C.; Pirrotta, E.; Ubaldi, E.; Bertolusso, L.; Zamparella, M.; De Polo, M.; et al. Association between coeliac disease and psoriasis: Italian primary care multicentre study. Dermatology 2015, 230, 156-160. [CrossRef]

66. Bhatia, B.K.; Millsop, J.W.; Debbaneh, M.; Koo, J.; Linos, E.; Liao, W. Diet and psoriasis, part II: Celiac disease and role of a gluten-free diet. J. Am. Acad. Dermatol. 2014, 71, 350-358. [CrossRef]

67. Khan, J.M.; Rao, S.U.; Rathore, M.U.; Janjua, W. Association between psoriasis and coeliac disease related antibodies. J. Ayub Med. Coll. Abbottabad 2014, 26, 203-206. [PubMed]

68. Weisenseel, P.; Kuznetsov, A.V.; Ruzicka, T.; Prinz, J.C. Palmoplantar pustulosis is not inevitably associated with antigliadin antibodies. Br. J. Dermatol. 2007, 156, 1399-1400. [CrossRef] [PubMed]

69. Nagui, N.; El Nabarawy, E.; Mahgoub, D.; Mashaly, H.M.; Saad, N.E.; El-Deeb, D.F. Estimation of (IgA) anti-gliadin, anti-endomysium and tissue transglutaminase in the serum of patients with psoriasis. Clin. Exp. Dermatol. 2011, 36, 302-304. [CrossRef] [PubMed]

70. Michaelsson, G.; Gerden, B.; Ottosson, M.; Parra, A.; Sjoberg, O.; Hjelmquist, G.; Loof, L. Patients with psoriasis often have increased serum levels of IgA antibodies to gliadin. Br. J. Dermatol. 1993, 129, 667-673. [CrossRef] [PubMed]

71. Singh, S.; Sonkar, G.K.; Usha; Singh, S. Celiac disease-associated antibodies in patients with psoriasis and correlation with HLA Cw6. J. Clin. Lab. Anal. 2010, 24, 269-272. [CrossRef] [PubMed]

72. Damasiewicz-Bodzek, A.; Wielkoszyński, T. Serologic markers of celiac disease in psoriatic patients. J. Eur. Acad. Dermatol. Venereol. 2008, 22, 1055-1061. [CrossRef]

73. Sultan, S.J.; Ahmad, Q.M.; Sultan, S.T. Antigliadin antibodies in psoriasis. Australas. J. Dermatol. 2010, 51, 238-242. [CrossRef]

74. Skavland, J.; Shewry, P.R.; Marsh, J.; Geisner, B.; Marcusson, J.A. In vitro screening for putative psoriasis-specific antigens among wheat proteins and peptides. Br. J. Dermatol. 2012, 166, 67-73. [CrossRef]

75. Akbulut, S.; Gür, G.; Topal, F.; Senel, E.; Topal, F.E.; Alli, N.; Saritas, U. Coeliac disease-associated antibodies in psoriasis. Ann. Dermatol. 2013, 25, 298-303. [CrossRef]

76. Cardinali, C.; Degl'innocenti, D.; Caproni, M.; Fabbri, P. Is the search for serum antibodies to gliadin, endomysium and tissue transglutaminase meaningful in psoriatic patients? Relationship between the pathogenesis of psoriasis and coeliac disease. Br. J. Dermatol. 2002, 147, 180-195. [CrossRef]

77. Kalayciyan, A.; Kotogyan, A. Psoriasis, enteropathy and antigliadin antibodies. Br. J. Dermatol. 2006, 154, 778-779. [CrossRef] [PubMed]

78. Kia, K.F.; Nair, R.P.; Ike, R.W.; Hiremagalore, R.; Elder, J.T.; Ellis, C.N. Prevalence of Antigliadin Antibodies in Patients with Psoriasis is Not Elevated Compared with Controls. Am. J. Clin. Dermatol. 2007, 8, 301-305. [CrossRef] [PubMed]

79. Lesiak, A.; Bednarski, I.; Pałczyńska, M.; Kumiszcza, E.; Kraska-Gacka, M.; Woźniacka, A.; Narbutt, J. Are interleukin-15 and -22 a new pathogenic factor in pustular palmoplantar psoriasis? Postepy. Dermatol. Alergol. 2016, 33, 336-339. [CrossRef] [PubMed]

80. Woo, W.K.; McMillan, S.A.; Watson, R.G.P.; McCluggage, W.G.; Sloan, J.M.; McMillan, J.C. Coeliac disease-associated antibodies correlate with psoriasis activity. Br. J. Dermatol. 2004, 151, 891-894. [CrossRef] 
81. Qiu, J.; Yuan, Y.; Li, Y.; Haley, C.; Mui, U.N.; Swali, R.; Mohan, C.; Tyring, S.K.; Wu, T. Discovery of IgG4 Anti-Gliadin Autoantibody as a Potential Biomarker of Psoriasis Using an Autoantigen Array. Proteom. Clin. Appl. 2020, 14, e1800114. [CrossRef]

82. Teichmann, J.; Voglau, M.J.; Lange, U. Antibodies to human tissue transglutaminase and alterations of vitamin D metabolism in ankylosing spondylitis and psoriatic arthritis. Rheumatol. Int. 2010, 30, 1559-1563. [CrossRef]

83. Zamani, F.; Alizadeh, S.; Amiri, A.; Shakeri, R.; Robati, M.; Alimohamadi, S.M.; Abdi, H.; Malekzadeh, R. Psoriasis and coeliac disease; is there any relationship? Acta Derm.-Venereol. 2010, 90, 295-296. [CrossRef]

84. Hull, C.M.; Liddle, M.; Hansen, N.; Meyer, L.J.; Schmidt, L.; Taylor, T.; Jaskowski, T.D.; Hill, H.R.; Zone, J.J. Elevation of IgA anti-epidermal transglutaminase antibodies in dermatitis herpetiformis. Br. J. Dermatol. 2008, 159, 120-124. [CrossRef]

85. Juzlova, K.; Votrubova, J.; Dzambova, M.; Gopfertova, D.; Hercogova, J.; Smerhovsky, Z. Gastrointestinal comorbidities in patients with psoriasis in the Czech Republic: The results of 189 patients with psoriasis and 378 controls. Biomed. Pap. Med. Fac. Univ. Palacky Olomouc Czech. Repub. 2016, 160, 100-105. [CrossRef]

86. Montesu, M.A.; Dessì-Fulgheri, C.; Pattaro, C.; Ventura, V.; Satta, R.; Cottoni, F. Association between psoriasis and coeliac disease? A case-control study. Acta Derm. Venereol. 2011, 91, 92-93. [CrossRef]

87. Ojetti, V.; Aguilar Sanchez, J.; Guerriero, C.; Fossati, B.; Capizzi, R.; De Simone, C.; Migneco, A.; Amerio, P.; Gasbarrini, G.; Gasbarrini, A. High Prevalence of Celiac Disease in Psoriasis. Am. J. Gastroenterol. 2003, 98, 2574-2575. [CrossRef]

88. Riente, L.; Chimenti, D.; Pratesi, F.; Delle Sedie, A.; Tommasi, S.; Tommasi, C.; Bombardieri, S.; Migliorini, P. Antibodies to tissue transglutaminase and Saccharomyces cerevisiae in ankylosing spondylitis and psoriatic arthritis. J. Rheumatol. 2004, 31, 920-924. [PubMed]

89. Singh, P.; Arora, A.; Strand, T.A.; Leffler, D.A.; Catassi, C.; Green, P.H.; Kelly, C.P.; Ahuja, V.; Makharia, G.K. Global Prevalence of Celiac Disease: Systematic Review and Meta-analysis. Clin. Gastroenterol. Hepatol. 2018, 16, 823-836. [CrossRef] [PubMed]

90. Acharya, P.; Mathur, M. Association between psoriasis and celiac disease: A systematic review and meta-analysis. J. Am. Acad. Dermatol. 2020, 82, 1376-1385. [CrossRef]

91. Aletaha, D.; Epstein, A.J.; Skup, M.; Zueger, P.; Garg, V.; Panaccione, R. Risk of Developing Additional Immune-Mediated Manifestations: A Retrospective Matched Cohort Study. Adv. Ther. 2019, 36, 1672-1683. [CrossRef]

92. Egeberg, A.; Griffiths, C.E.M.; Mallbris, L.; Gislason, G.H.; Skov, L. The association between psoriasis and coeliac disease. Br. J. Dermatol. 2017, 177, e329-e330. [CrossRef]

93. Ludvigsson, J.F.; Lindelöf, B.; Zingone, F.; Ciacci, C. Psoriasis in a Nationwide Cohort Study of Patients with Celiac Disease. J. Investig. Dermatol. 2011, 131, 2010-2016. [CrossRef]

94. Birkenfeld, S.; Dreiher, J.; Weitzman, D.; Cohen, A.D. Coeliac disease associated with psoriasis. Br. J. Dermatol. 2009, 161, 1331-1334. [CrossRef]

95. Wu, J.J.; Nguyen, T.U.; Poon, K.-Y.T.; Herrinton, L.J. The association of psoriasis with autoimmune diseases. J. Am. Acad. Dermatol. 2012, 67, 924-930. [CrossRef]

96. Merola, J.F.; Herrera, V.; Palmer, J.B. Direct healthcare costs and comorbidity burden among patients with psoriatic arthritis in the USA. Clin. Rheumatol. 2018, 37, 2751-2761. [CrossRef]

97. Blegvad, C.; Egeberg, A.; Tind Nielsen, T.E.; Gislason, G.H.; Zachariae, C.; Nybo Andersen, A.-M.; Skov, L. Autoimmune Disease in Children and Adolescents with Psoriasis: A Cross-sectional Study in Denmark. Acta Derm. Venereol. 2017, 97, 1225-1229. [CrossRef] [PubMed]

98. Zohar, A.; Cohen, A.D.; Bitterman, H.; Feldhamer, I.; Greenberg-Dotan, S.; Lavi, I.; Comanesther, D.; Batat, E.; Zisman, D. Gastrointestinal comorbidities in patients with psoriatic arthritis. Clin. Rheumatol. 2016, 35, 2679-2684. [CrossRef] [PubMed]

99. Iqbal, T.; Zaidi, M.A.; Wells, G.A.; Karsh, J. Celiac disease arthropathy and autoimmunity study. J. Gastroenterol. Hepatol. 2013, 28, 99-105. [CrossRef] [PubMed]

100. Assa, A.; Frenkel-Nir, Y.; Tzur, D.; Katz, L.H.; Shamir, R. Large population study shows that adolescents with celiac disease have an increased risk of multiple autoimmune and nonautoimmune comorbidities. Acta Paediatr. 2017, 106, 967-972. [CrossRef]

101. Collin, P.; Reunala, T.; Pukkala, E.; Laippala, P.; Keyrilainen, O.; Pasternack, A. Coeliac disease-associated disorders and survival. Gut 1994, 35, 1215-1218. [CrossRef] 
102. Ventura, A.; Magazzù, G.; Greco, L. Duration of exposure to gluten and risk for autoimmune disorders in patients with celiac disease. SIGEP Study Group for Autoimmune Disorders in Celiac Disease. Gastroenterology 1999, 117, 297-303. [CrossRef]

103. Sategna Guidetti, C.; Solerio, E.; Scaglione, N.; Aimo, G.; Mengozzi, G. Duration of gluten exposure in adult coeliac disease does not correlate with the risk for autoimmune disorders. Gut 2001, 49, 502-505. [CrossRef]

104. Bibbò, S.; Pes, G.M.; Usai-Satta, P.; Salis, R.; Soro, S.; Quarta Colosso, B.M.; Dore, M.P. Chronic autoimmune disorders are increased in coeliac disease: A case-control study. Medicine 2017, 96, e8562. [CrossRef]

105. Antvorskov, J.C.; Josefsen, K.; Engkilde, K.; Funda, D.P.; Buschard, K. Dietary gluten and the development of type 1 diabetes. Diabetologia 2014, 57, 1770-1780. [CrossRef]

106. Haupt-Jorgensen, M.; Holm, L.; Josefsen, K.; Buschard, K. Possible Prevention of Diabetes with a Gluten-Free Diet. Nutrients 2018, 10, 1746. [CrossRef]

107. Antvorskov, J.C.; Halldorsson, T.I.; Josefsen, K.; Svensson, J.; Granström, C.; Roep, B.O.; Olesen, T.H.; Hrolfsdottir, L.; Buschard, K.; Olsen, S.F. Association between maternal gluten intake and type 1 diabetes in offspring: National prospective cohort study in Denmark. BMJ 2018, 362, k3547. [CrossRef] [PubMed]

108. Lund-Blix, N.A.; Tapia, G.; Marild, K.; Brantsaeter, A.L.; Njolstad, P.R.; Joner, G.; Skrivarhaug, T.; Størdal, K.; Stene, L.C. Maternal and child gluten intake and association with type 1 diabetes: The Norwegian Mother and Child Cohort Study. PLoS Med. 2020, 17, e1003032. [CrossRef] [PubMed]

109. Virtanen, S.M.; Uusitalo, L.; Kenward, M.G.; Nevalainen, J.; Uusitalo, U.; Kronberg-Kippilä, C.; Ovaskainen, M.-L.; Arkkola, T.; Niinistö, S.; Hakulinen, T.; et al. Maternal food consumption during pregnancy and risk of advanced $\beta$-cell autoimmunity in the offspring. Pediatr. Diabetes 2011, 12, 95-99. [CrossRef] [PubMed]

110. Lamb, M.M.; Myers, M.A.; Barriga, K.; Zimmet, P.Z.; Rewers, M.; Norris, J.M. Maternal diet during pregnancy and islet autoimmunity in offspring. Pediatr. Diabetes 2008, 9, 135-141. [CrossRef]

111. Norris, J.M.; Barriga, K.; Klingensmith, G.; Hoffman, M.; Eisenbarth, G.S.; Erlich, H.A.; Rewers, M. Timing of initial cereal exposure in infancy and risk of islet autoimmunity. JAMA 2003, 290, 1713-1720. [CrossRef]

112. Wahlberg, J.; Vaarala, O.; Ludvigsson, J.; The ABIS-Study Group. Dietary risk factors for the emergence of type 1 diabetes-related autoantibodies in $2 \frac{1}{2}$-year-old Swedish children. Br. J. Nutr. 2006, 95, 603-608. [CrossRef]

113. Ludvigsson, J. Cow-Milk-Free Diet during Last Trimester of Pregnancy Does Not Influence Diabetes-Related Autoantibodies in Nondiabetic Children. Ann. N. Y. Acad. Sci. 2003, 1005, 275-278. [CrossRef]

114. Ziegler, A.-G.; Schmid, S.; Huber, D.; Hummel, M.; Bonifacio, E. Early infant feeding and risk of developing type 1 diabetes-associated autoantibodies. JAMA 2003, 290, 1721-1728. [CrossRef]

115. Hummel, S.; Pfluger, M.; Hummel, M.; Bonifacio, E.; Ziegler, A.-G. Primary Dietary Intervention Study to Reduce the Risk of Islet Autoimmunity in Children at Increased Risk for Type 1 Diabetes: The BABYDIET study. Diabetes Care 2011, 34, 1301-1305. [CrossRef]

116. Pastore, M.-R.; Bazzigaluppi, E.; Belloni, C.; Arcovio, C.; Bonifacio, E.; Bosi, E. Six Months of Gluten-Free Diet Do Not Influence Autoantibody Titers, but Improve Insulin Secretion in Subjects at High Risk for Type 1 Diabetes. J. Clin. Endocrinol. Metab. 2003, 88, 162-165. [CrossRef]

117. Füchtenbusch, M.; Ziegler, A.-G.; Hummel, M. Elimination of dietary gluten and development of type 1 diabetes in high risk subjects. Rev. Diabet. Stud. 2004, 1, 39-41. [CrossRef] [PubMed]

118. Sildorf, S.M.; Fredheim, S.; Svensson, J.; Buschard, K. Remission without insulin therapy on gluten-free diet in a 6-year old boy with type 1 diabetes mellitus. Case Rep. 2012, 2012, bcr0220125878. [CrossRef] [PubMed]

119. Svensson, J.; Sildorf, S.M.; Pipper, C.B.; Kyvsgaard, J.N.; Bøjstrup, J.; Pociot, F.M.; Mortensen, H.B.; Buschard, K. Potential beneficial effects of a gluten-free diet in newly diagnosed children with type 1 diabetes: A pilot study. Springerplus 2016, 5, 994. [CrossRef] [PubMed]

120. Neuman, V.; Pruhova, S.; Kulich, M.; Kolouskova, S.; Vosahlo, J.; Romanova, M.; Petruzelkova, L.; Obermannova, B.; Funda, D.P.; Cinek, O.; et al. Gluten-free diet in children with recent-onset type 1 diabetes: A 12-month intervention trial. Diabetes Obes. Metab. 2020, 22, 866-872. [CrossRef]

121. Abid, N.; McGlone, O.; Cardwell, C.; McCallion, W.; Carson, D. Clinical and metabolic effects of gluten free diet in children with type 1 diabetes and coeliac disease. Pediatr. Diabetes 2011, 12, 322-325. [CrossRef] [PubMed] 
122. Acerini, C.L.; Ahmed, M.L.; Ross, K.M.; Sullivan, P.B.; Bird, G.; Dunger, D.B. Coeliac disease in children and adolescents with IDDM: Clinical characteristics and response to gluten-free diet. Diabet. Med. 1998, 15, 38-44. [CrossRef]

123. Amin, R.; Murphy, N.; Edge, J.; Ahmed, M.L.; Acerini, C.L.; Dunger, D.B. A longitudinal study of the effects of a gluten-free diet on glycemic control and weight gain in subjects with type 1 diabetes and celiac disease. Diabetes Care 2002, 25, 1117-1122. [CrossRef]

124. Bakker, S.F.; Tushuizen, M.E.; von Blomberg, M.E.; Mulder, C.J.; Simsek, S. Type 1 diabetes and celiac disease in adults: Glycemic control and diabetic complications. Acta Diabetol. 2013, 50, 319-324. [CrossRef]

125. Fröhlich-Reiterer, E.E.; Kaspers, S.; Hofer, S.; Schober, E.; Kordonouri, O.; Pozza, S.B.-D.; Holl, R.W. Anthropometry, Metabolic Control, and Follow-Up in Children and Adolescents with Type 1 Diabetes Mellitus and Biopsy-Proven Celiac Disease. J. Pediatr. 2011, 158, 589-593. [CrossRef]

126. Goh, V.L.; Estrada, D.E.; Lerer, T.; Balarezo, F.; Sylvester, F.A. Effect of gluten-free diet on growth and glycemic control in children with type 1 diabetes and asymptomatic celiac disease. J. Pediatr. Endocrinol. Metab. 2010, 23, 1169-1173. [CrossRef]

127. Hansen, D.; Brock-Jacobsen, B.; Lund, E.; Bjørn, C.; Hansen, L.P.; Nielsen, C.; Fenger, C.; Lillevang, S.T.; Husby, S. Clinical benefit of a gluten-free diet in type 1 diabetic children with screening-detected celiac disease: A population-based screening study with 2 years' follow-up. Diabetes Care 2006, 29, 2452-2456. [CrossRef] [PubMed]

128. Kaspers, S.; Kordonouri, O.; Schober, E.; Grabert, M.; Hauffa, B.P.; Holl, R.W. Anthropometry, metabolic control, and thyroid autoimmunity in type 1 diabetes with celiac disease: A multicenter survey. J. Pediatr. 2004, 145, 790-795. [CrossRef] [PubMed]

129. Kaur, P.; Agarwala, A.; Makharia, G.; Bhatnagar, S.; Tandon, N. Effect of gluten-free diet on metabolic control and anthropometric parameters in type 1 diabetes with subclinical celiac disease: A randomized controlled trial. Endocr. Pract. 2020, 26, 660-667. [CrossRef] [PubMed]

130. Kaukinen, K.; Salmi, J.; Lahtela, J.; Siljamaki-Ojansuu, U.; Koivisto, A.M.; Oksa, H.; Collin, P. No effect of gluten-free diet on the metabolic control of type 1 diabetes in patients with diabetes and celiac disease. Retrospective and controlled prospective survey. Diabetes Care 1999, 22, 1747-1748. [CrossRef]

131. Leeds, J.S.; Hopper, A.D.; Hadjivassiliou, M.; Tesfaye, S.; Sanders, D.S. High prevalence of microvascular complications in adults with type 1 diabetes and newly diagnosed celiac disease. Diabetes Care 2011, 34, 2158-2163. [CrossRef]

132. Mohn, A.; Cerruto, M.; Iafusco, D.; Prisco, F.; Tumini, S.; Stoppoloni, O.; Chiarelli, F. Celiac disease in children and adolescents with type I diabetes: Importance of hypoglycemia. J. Pediatr. Gastroenterol. Nutr. 2001, 32, 37-40. [CrossRef]

133. Narula, P.; Porter, L.; Langton, J.; Rao, V.; Davies, P.; Cummins, C.; Kirk, J.; Barrett, T.; Protheroe, S. Gastrointestinal symptoms in children with type 1 diabetes screened for celiac disease. Pediatrics 2009, 124, e489-e495. [CrossRef]

134. Pham-Short, A.; Donaghue, K.C.; Ambler, G.; Chan, A.K.; Hing, S.; Cusumano, J.; Craig, M.E. Early elevation of albumin excretion rate is associated with poor gluten-free diet adherence in young people with coeliac disease and diabetes. Diabet. Med. 2014, 31, 208-212. [CrossRef]

135. Poulain, C.; Johanet, C.; Delcroix, C.; Lévy-Marchal, C.; Tubiana-Rufi, N. Prevalence and clinical features of celiac disease in 950 children with type 1 diabetes in France. Diabetes Metab. 2007, 33, 453-458. [CrossRef]

136. Rami, B.; Sumnik, Z.; Schober, E.; Waldhör, T.; Battelino, T.; Bratanic, N.; Kürti, K.; Lebl, J.; Limbert, C.; Madacsy, L.; et al. Screening Detected Celiac Disease in Children with Type 1 Diabetes Mellitus: Effect on the Clinical Course (A Case Control Study). J. Pediatr. Gastroenterol. Nutr. 2005, 41, 317-321. [CrossRef]

137. Sanchez-Albisua, I.; Wolf, J.; Neu, A.; Geiger, H.; Wäscher, I.; Stern, M. Coeliac disease in children with Type 1 diabetes mellitus: The effect of the gluten-free diet. Diabet. Med. 2005, 22, 1079-1082. [CrossRef] [PubMed]

138. Saukkonen, T.; Väisänen, S.; Akerblom, H.K.; Savilahti, E. Childhood Diabetes in Finland Study Group Coeliac disease in children and adolescents with type 1 diabetes: A study of growth, glycaemic control, and experiences of families. Acta Paediatr. 2002, 91, 297-302. [CrossRef] [PubMed]

139. Sun, S.; Puttha, R.; Ghezaiel, S.; Skae, M.; Cooper, C.; Amin, R.; North West England Paediatric. Diabetes Network The effect of biopsy-positive silent coeliac disease and treatment with a gluten-free diet on growth and glycaemic control in children with Type 1 diabetes. Diabet. Med. 2009, 26, 1250-1254. [CrossRef] [PubMed] 
140. Saadah, O.I.; Zacharin, M.; O'Callaghan, A.; Oliver, M.R.; Catto-Smith, A.G. Effect of gluten-free diet and adherence on growth and diabetic control in diabetics with coeliac disease. Arch. Dis. Child. 2004, 89, 871-876. [CrossRef] [PubMed]

141. Valletta, E.; Ulmi, D.; Mabboni, I.; Tomasselli, F.; Pinelli, L. Early diagnosis and treatment of celiac disease in type 1 diabetes. A longitudinal, case-control study. Med Surg. Pediatr. 2007, 29, 99-104.

142. Westman, E.; Ambler, G.R.; Royle, M.; Peat, J.; Chan, A. Children with coeliac disease and insulin dependent diabetes mellitus-growth, diabetes control and dietary intake. J. Pediatr. Endocrinol. Metab. 1999, 12, $433-442$. [CrossRef] [PubMed]

143. Elfström, P.; Sundström, J.; Ludvigsson, J.F. Systematic review with meta-analysis: Associations between coeliac disease and type 1 diabetes. Aliment. Pharmacol. Ther. 2014, 40, 1123-1132. [CrossRef]

144. Nederstigt, C.; Uitbeijerse, B.S.; Janssen, L.G.M.; Corssmit, E.P.M.; de Koning, E.J.P.; Dekkers, O.M. Associated auto-immune disease in type 1 diabetes patients: A systematic review and meta-analysis. Eur. J. Endocrinol. 2019, 180, 135-144. [CrossRef]

145. Ludvigsson, J.F.; Ludvigsson, J.; Ekbom, A.; Montgomery, S.M. Celiac Disease and Risk of Subsequent Type 1 Diabetes: A general population cohort study of children and adolescents. Diabetes Care 2006, 29, 2483-2488. [CrossRef]

146. Tiberti, C.; Panimolle, F.; Bonamico, M.; Filardi, T.; Pallotta, L.; Nenna, R.; Pontone, S.; Dotta, F.; Pugliese, G.; Lenzi, A.; et al. Long-standing type 1 diabetes: Patients with adult-onset develop celiac-specific immunoreactivity more frequently than patients with childhood-onset diabetes, in a disease duration-dependent manner. Acta Diabetol. 2014, 51, 675-678. [CrossRef]

147. Tiberti, C.; Panimolle, F.; Bonamico, M.; Shashaj, B.; Filardi, T.; Lucantoni, F.; Nenna, R.; Costantino, F.; Lenzi, A.; Morano, S. IgA anti-transglutaminase autoantibodies at type 1 diabetes onset are less frequent in adult patients and are associated with a general celiac-specific lower immune response in comparison with nondiabetic celiac patients at diagnosis. Diabetes Care 2012, 35, 2083-2085. [CrossRef] [PubMed]

148. Smith, C.M.; Clarke, C.F.; Porteous, L.E.; Elsori, H.; Cameron, D.J.S. Prevalence of coeliac disease and longitudinal follow-up of antigliadin antibody status in children and adolescents with type 1 diabetes mellitus. Pediatr. Diabetes 2000, 1, 199-203. [CrossRef] [PubMed]

149. Ventura, A.; Neri, E.; Ughi, C.; Leopaldi, A.; Città, A.; Not, T. Gluten-dependent diabetes-related and thyroid-related autoantibodies in patients with celiac disease. J. Pediatr. 2000, 137, 263-265. [CrossRef] [PubMed]

150. Salardi, S.; Volta, U.; Zucchini, S.; Fiorini, E.; Maltoni, G.; Vaira, B.; Cicognani, A. Prevalence of Celiac Disease in Children With Type 1 Diabetes Mellitus Increased in the Mid-1990s: An 18-year Longitudinal Study Based on Anti-endomysial Antibodies. J. Pediatr. Gastroenterol. Nutr. 2008, 46, 612-614. [CrossRef]

151. Krysiak, R.; Szkróbka, W.; Okopień, B. The Effect of Gluten-Free Diet on Thyroid Autoimmunity in Drug-Naïve Women with Hashimoto's Thyroiditis: A Pilot Study. Exp. Clin. Endocrinol. Diabetes 2019, 127, 417-422. [CrossRef]

152. Sategna-Guidetti, C.; Volta, U.; Ciacci, C.; Usai, P.; Carlino, A.; De Franceschi, L.; Camera, A.; Pelli, A.; Brossa, C. Prevalence of thyroid disorders in untreated adult celiac disease patients and effect of gluten withdrawal: An Italian multicenter study. Am. J. Gastroenterol. 2001, 96, 751-757. [CrossRef]

153. Valentino, R.; Savastano, S.; Tommaselli, A.P.; Dorato, M.; Scarpitta, M.T.; Gigante, M.; Micillo, M.; Paparo, F.; Petrone, E.; Lombardi, G.; et al. Prevalence of Coeliac Disease in Patients with Thyroid Autoimmunity. Horm. Res. Paediatr. 1999, 51, 124-127. [CrossRef]

154. Mainardi, E.; Montanelli, A.; Dotti, M.; Nano, R.; Moscato, G. Thyroid-related autoantibodies and celiac disease: A role for a gluten-free diet? J. Clin. Gastroenterol. 2002, 35, 245-248. [CrossRef]

155. Metso, S.; Hyytiä-Ilmonen, H.; Kaukinen, K.; Huhtala, H.; Jaatinen, P.; Salmi, J.; Taurio, J.; Collin, P. Gluten-free diet and autoimmune thyroiditis in patients with celiac disease. A prospective controlled study. Scand. J. Gastroenterol. 2012, 47, 43-48. [CrossRef]

156. Virili, C.; Bassotti, G.; Santaguida, M.G.; Iuorio, R.; Del Duca, S.C.; Mercuri, V.; Picarelli, A.; Gargiulo, P.; Gargano, L.; Centanni, M. Atypical celiac disease as cause of increased need for thyroxine: A systematic study. J. Clin. Endocrinol. Metab. 2012, 97, E419-E422. [CrossRef]

157. Zubarik, R.; Nathan, M.; Vahora, H.; Ganguly, E.K.; Vecchio, J. Su1435 Hypothyroid Patients Requiring Elevated Doses of Levothyroxine to Maintain a Euthyroid State Should Be Tested for Celiac Disease (CD). Gastroenterology 2014, 146, S-468. [CrossRef] 
158. Sharma, B.R.; Joshi, A.S.; Varthakavi, P.K.; Chadha, M.D.; Bhagwat, N.M.; Pawal, P.S. Celiac autoimmunity in autoimmune thyroid disease is highly prevalent with a questionable impact. Indian J. Endocrinol. Metab. 2016, 20, 97-100. [CrossRef] [PubMed]

159. Ch'ng, C.L.; Biswas, M.; Benton, A.; Jones, M.K.; Kingham, J.G.C. Prospective screening for coeliac disease in patients with Graves' hyperthyroidism using anti-gliadin and tissue transglutaminase antibodies. Clin. Endocrinol. 2005, 62, 303-306. [CrossRef]

160. Guliter, S.; Yakaryilmaz, F.; Ozkurt, Z.; Ersoy, R.; Ucardag, D.; Caglayan, O.; Atasoy, P. Prevalence of coeliac disease in patients with autoimmune thyroiditis in a Turkish population. World J. Gastroenterol. 2007, 13, 1599. [CrossRef] [PubMed]

161. Hadithi, M. Coeliac disease in Dutch patients with Hashimoto's thyroiditis and vice versa. World J. Gastroenterol. 2007, 13, 1715. [CrossRef] [PubMed]

162. Jiskra, J.; Límanová, Z.; Vanícková, Z.; Kocna, P. IgA and IgG antigliadin, IgA anti-tissue transglutaminase and antiendomysial antibodies in patients with autoimmune thyroid diseases and their relationship to thyroidal replacement therapy. Physiol. Res. 2003, 52, 79-88. [PubMed]

163. Mankaï, A.; Chadli-Chaieb, M.; Saad, F.; Ghedira-Besbes, L.; Ouertani, M.; Sfar, H.; Limem, M.; Ben Abdessalem, M.; Jeddi, M.; Chaieb, L.; et al. Screening for celiac disease in Tunisian patients with Graves' disease using anti-endomysium and anti-tissue transglutaminase antibodies. Gastroentérol. Clin. ET Biol. 2006, 30, 961-964. [CrossRef]

164. Marwaha, R.K.; Garg, M.K.; Tandon, N.; Kanwar, R.; Narang, A.; Sastry, A.; Saberwal, A.; Bhadra, K. Glutamic acid decarboxylase (anti-GAD) \& tissue transglutaminase (anti-TTG) antibodies in patients with thyroid autoimmunity. Indian J. Med. Res. 2013, 137, 82-86.

165. Mehrdad, M.; Mansour-Ghanaei, F.; Mohammadi, F.; Joukar, F.; Dodangeh, S.; Mansour-Ghanaei, R. Frequency of Celiac Disease in Patients with Hypothyroidism. J. Thyroid. Res. 2012, 2012, 1-6. [CrossRef]

166. Meloni, G.F.; Tomasi, P.A.; Bertoncelli, A.; Fanciulli, G.; Delitala, G.; Meloni, T. Prevalence of silent celiac disease in patients with autoimmune thyroiditis from Northern Sardinia. J. Endocrinol. Investig. 2001, 24, 298-302. [CrossRef]

167. Ravaglia, G.; Forti, P.; Maioli, F.; Volta, U.; Arnone, G.; Pantieri, G.; Talerico, T.; Muscari, A.; Zoli, M. Increased prevalence of coeliac disease in autoimmune thyroiditis is restricted to aged patients. Exp. Gerontol. 2003, 38, 589-595. [CrossRef]

168. Hadizadeh Riseh, S.; Abbasalizad Farhang, M.; Mobasseri, M.; Asghari Jafarabadi, M. The Relationship between Thyroid Hormones, Antithyroid Antibodies, Anti-Tissue Transglutaminase and Anti-Gliadin Antibodies in Patients with Hashimoto's Thyroiditis. Acta Endocrinol. 2017, 13, 174-179.

169. Sahin, Y.; Evliyaoglu, O.; Erkan, T.; Cokugras, F.C.; Ercan, O.; Kutlu, T. The frequency of celiac disease in children with autoimmune thyroiditis. Acta Gastroenterol. Belg. 2018, 81, 5-8. [PubMed]

170. Sari, S.; Yesilkaya, E.; Egritas, O.; Bideci, A.; Dalgic, B. Prevalence of Celiac Disease in Turkish Children with Autoimmune Thyroiditis. Dig. Dis. Sci. 2009, 54, 830-832. [CrossRef]

171. Sattar, N.; Lazare, F.; Kacer, M.; Aguayo-Figueroa, L.; Desikan, V.; Garcia, M.; Lane, A.; Chawla, A.; Wilson, T. Celiac Disease in Children, Adolescents, and Young Adults with Autoimmune Thyroid Disease. J. Pediatri. 2011, 158, 272.e1-275.e1. [CrossRef]

172. Spadaccino, A.C.; Basso, D.; Chiarelli, S.; Albergoni, M.P.; D’Odorico, A.; Plebani, M.; Pedini, B.; Lazzarotto, F.; Betterle, C. Celiac disease in North Italian patients with autoimmune thyroid diseases. Autoimmunity 2008, 41, 116-121. [CrossRef]

173. Tuhan, H.; Işık, S.; Abacı, A.; Şimşek, E.; Anık, A.; Anal, Ö.; Böber, E. Celiac disease in children and adolescents with Hashimoto Thyroiditis. Turk Pediatri Ars 2016, 51, 100-105. [CrossRef]

174. Twito, O.; Shapiro, Y.; Golan-Cohen, A.; Dickstein, Y.; Ness-Abramof, R.; Shapiro, M. Anti-thyroid antibodies, parietal cell antibodies and tissue transglutaminase antibodies in patients with autoimmune thyroid disease. Arch. Med. Sci. 2018, 14, 516-520. [CrossRef]

175. Valentino, R.; Savastano, S.; Maglio, M.; Paparo, F.; Ferrara, F.; Dorato, M.; Lombardi, G.; Troncone, R. Markers of potential coeliac disease in patients with Hashimoto's thyroiditis. Eur. J. Endocrinol. 2002, 479-483. [CrossRef]

176. Ventura, A.; Ronsoni, M.F.; Shiozawa, M.B.C.; Dantas-Corrêa, E.B.; Canalli, M.H.B.d.S.; Schiavon, L.d.L.; Narciso-Schiavon, J.L. Prevalence and clinical features of celiac disease in patients with autoimmune thyroiditis: Cross-sectional study. Sao Paulo Med. J. 2014, 132, 364-371. [CrossRef] 
177. Volta, U.; Ravaglia, G.; Granito, A.; Forti, P.; Maioli, F.; Petrolini, N.; Zoli, M.; Bianchi, F.B. Coeliac Disease in Patients with Autoimmune Thyroiditis. Digestion 2001, 64, 61-65. [CrossRef] [PubMed]

178. Zhao, Z.; Zou, J.; Zhao, L.; Cheng, Y.; Cai, H.; Li, M.; Liu, E.; Yu, L.; Liu, Y. Celiac Disease Autoimmunity in Patients with Autoimmune Diabetes and Thyroid Disease among Chinese Population. PLoS ONE 2016, 11, e0157510. [CrossRef] [PubMed]

179. Zubarik, R.; Ganguly, E.; Nathan, M.; Vecchio, J. Celiac disease detection in hypothyroid patients requiring elevated thyroid supplementation: A prospective cohort study. Eur. J. Intern. Med. 2015, 26, 825-829. [CrossRef] [PubMed]

180. Kaličanin, D.; Brčić, L.; Barić, A.; Zlodre, S.; Barbalić, M.; Lovrić, V.T.; Punda, A.; Perica, V.B. Evaluation of Correlations Between Food-Specific Antibodies and Clinical Aspects of Hashimoto's Thyroiditis. J. Am. Coll. Nutr. 2019, 38, 259-266. [CrossRef]

181. Sjöberg, K.; Wassmuth, R.; Reichstetter, S.; Eriksson, K.F.; Ericsson, U.B.; Eriksson, S. Gliadin antibodies in adult insulin-dependent diabetes-autoimmune and immunogenetic correlates. Autoimmunity 2000, 32, 217-228. [CrossRef]

182. Naiyer, A.J.; Shah, J.; Hernandez, L.; Kim, S.-Y.; Ciaccio, E.J.; Cheng, J.; Manavalan, S.; Bhagat, G.; Green, P.H.R. Tissue transglutaminase antibodies in individuals with celiac disease bind to thyroid follicles and extracellular matrix and may contribute to thyroid dysfunction. Thyroid 2008, 18, 1171-1178. [CrossRef]

183. Chong, J.S.W.L.V.; Li Voon, J.S.; Leong, K.S.; Wallymahmed, M.; Sturgess, R.; MacFarlane, I.A. Is coeliac disease more prevalent in young adults with coexisting Type 1 diabetes mellitus and autoimmune thyroid disease compared with those with Type 1 diabetes mellitus alone? Diabet. Med. 2002, 19, 334-337. [CrossRef]

184. Kurien, M.; Mollazadegan, K.; Sanders, D.S.; Ludvigsson, J.F. Celiac Disease Increases Risk of Thyroid Disease in Patients With Type 1 Diabetes: A Nationwide Cohort Study. Diabetes Care 2016, 39, 371-375. [CrossRef]

185. Roy, A.; Laszkowska, M.; Sundström, J.; Lebwohl, B.; Green, P.H.R.; Kämpe, O.; Ludvigsson, J.F. Prevalence of Celiac Disease in Patients with Autoimmune Thyroid Disease: A Meta-Analysis. Thyroid 2016, 26, 880-890. [CrossRef]

186. Sun, X.; Lu, L.; Yang, R.; Li, Y.; Shan, L.; Wang, Y. Increased Incidence of Thyroid Disease in Patients with Celiac Disease: A Systematic Review and Meta-Analysis. PLoS ONE 2016, 11, e0168708. [CrossRef]

187. Ferrari, S.M.; Fallahi, P.; Ruffilli, I.; Elia, G.; Ragusa, F.; Benvenga, S.; Antonelli, A. The association of other autoimmune diseases in patients with Graves' disease (with or without ophthalmopathy): Review of the literature and report of a large series. Autoimmun. Rev. 2019, 18, 287-292. [CrossRef] [PubMed]

188. Baharvand, P.; Hormozi, M.; Aaliehpour, A. Comparison of thyroid disease prevalence in patients with celiac disease and controls. Gastroenterol. Hepatol. Bed. Bench 2020, 13, 44-49. [PubMed]

189. Canova, C.; Pitter, G.; Ludvigsson, J.F.; Romor, P.; Zanier, L.; Zanotti, R.; Simonato, L. Celiac Disease and Risk of Autoimmune Disorders: A Population-Based Matched Birth Cohort Study. J. Pediatr. 2016, 174, 146.e1-152.e1. [CrossRef]

190. Viljamaa, M.; Kaukinen, K.; Huhtala,H.; Kyrönpalo, S.; Rasmussen, M.; Collin, P. Coeliac Disease, autoimmune diseases and gluten exposure. Scand. J. Gastroenterol. 2005, 40, 437-443. [CrossRef]

191. Soni, S.; Agarwal, A.; Singh, A.; Gupta, V.; Khadgawat, R.; Chaturvedi, P.K.; Ahuja, V.; Makharia, G.K. Prevalence of thyroid autoimmunity in first-degree relatives of patients with celiac disease. Indian J. Gastroenterol. 2019, 38, 450-455. [CrossRef] [PubMed]

192. Castro, P.D.; Harkin, G.; Hussey, M.; Christopher, B.; Kiat, C.; Chin, J.L.; Trimble, V.; McNamara, D.; MacMathuna, P.; Egan, B.; et al. Prevalence of coexisting autoimmune thyroidal diseases in coeliac disease is decreasing. United Eur. Gastroenterol. J. 2020, 8, 148-156. [CrossRef]

193. Ríos León, R.; Crespo Pérez, L.; Rodríguez de Santiago, E.; Roy Ariño, G.; De Andrés Martín, A.; García Hoz Jiménez, C.; Sánchez Rodríguez, E.; Saiz González, A.; León Prieto, F.; Albillos, A. Genetic and flow cytometry analysis of seronegative celiac disease: A cohort study. Scand. J. Gastroenterol. 2019, 54, 563-570. [CrossRef]

194. Carroccio, A.; D'Alcamo, A.; Cavataio, F.; Soresi, M.; Seidita, A.; Sciumè, C.; Geraci, G.; Iacono, G.; Mansueto, P. High Proportions of People With Nonceliac Wheat Sensitivity Have Autoimmune Disease or Antinuclear Antibodies. Gastroenterology 2015, 149, 596.e1-603.e1. [CrossRef] 
195. Losurdo, G.; Principi, M.; Iannone, A.; Giangaspero, A.; Piscitelli, D.; Ierardi, E.; Di Leo, A.; Barone, M. Predictivity of Autoimmune Stigmata for Gluten Sensitivity in Subjects with Microscopic Enteritis: A Retrospective Study. Nutrients 2018, 10. [CrossRef]

196. Zettinig, G.; Weissel, M.; Flores, J.; Dudczak, R.; Vogelsang, H. Dermatitis herpetiformis is associated with atrophic but not with goitrous variant of Hashimoto's thyroiditis. Eur. J. Clin. Investig. 2000, 30, 53-57. [CrossRef]

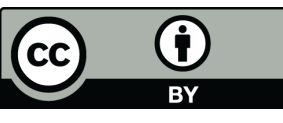

(C) 2020 by the authors. Licensee MDPI, Basel, Switzerland. This article is an open access article distributed under the terms and conditions of the Creative Commons Attribution (CC BY) license (http://creativecommons.org/licenses/by/4.0/). 